\title{
EFFECT OF TREFLAN HERBICIDE AND PHOSPHORUS LEVELSON WEEDS AND CHICK PEA YIELD
}

\author{
Mohammed Ali Hussan, Abbas Alo Khether, Fahmi Haji Mourad and Wisam Khalid Sabri \\ Dept. of field crops, Collegeof Agriculture, University of Dohuk, Kurdistan Region-Iraq.
}

(Received: October 26, 2017; Accepted for publication: December 28, 2017)

\begin{abstract}
A field experiment was conducted in Research Farm of Agriculture College, Duhok University during growing season of 2017 in tow sowing dates $(20 / 2$ and 10/3/1917) to investigate four levels of Treflan herbicide $\left(0,1.200,2.400\right.$, and 3.200) $\left.\mathrm{L} \mathrm{ha}^{-1,}\right)$ and four phosphorous level $\left((0,140,180\right.$ and 220$) \mathrm{Kg}_{2} \mathrm{O}_{5} \mathrm{ha}^{-1}$. on growth of weed, yield and yield components of chickpea. Treatments arranged in factorial experiment based on Randomized Complete Block Design (RCBD) with three replications. The results revealed that treflan and phosphorous levels showed considerable reduction on number and dry weight of broad narrow leaved weeds, and significant effect on yield and yield components of chickpea were recorded under interaction $\left(H_{3} P_{3} D_{1}\right)$ and produced the highest values $(1.5,76.4,34.3 \mathrm{~g}, 6.9 \mathrm{~g}$ and $58.3 \mathrm{~cm})$ for number of seeds pod $^{-1}$, seeds plant $^{-1}$, 100-grain weight, grain yield plant and height of the lowest pod.
\end{abstract}

KEYWORDS: Herbicide, weed, chickpea, yield

\section{INTRODUCTION}

C hick pea (Cicer arietinum L.) is second of the important conventional pulse crop in Kurdistan region Iraq. The chick pea yield is lowest as compared to the highest potential of cultivars. One of the most limiting factors is weed infestation. Chick pea is a low competitor to weeds because of its slow growth rate and restricted leaf area and slow development at the early stages of crop growth and establishment. Auld, .and Lee. (1981). Sawhncy, et al. (1985). Tewari, et al; (2001) reported that were redacts $80 \%$ of chick pea yield when weeds allowed to compete for full season. Several researchers reported that reduction in potential yield losses in chick pea due to weed range between $22 \%$ and $100 \%$ (Faroda, and Sing (1981), Sexena (1976) and Yadav, (1988), Bhalla et al, (1998). The using of herbicides pre or post-emergence increase with $12 \%-14 \%$ and $6 \%-23 \%$, respectively in a chick pea crop (Ahlawat, et al. 1981, Hassan and Khan, (2007). Weed pre emergence with the spring chick pea crop creates a severe competition unless controlled effectively and in a timely manner. Kumar and Sreenivasulu, (2004) reported that the number of pods and seed index was improved under higher phosphorous application. Several researchers reported about phosphorous application in chick pea (Mahajan and Sharma, (2005); Gawai and Pawar, 2007), and found long term fertilizer experiments involving intensive cereal based cropping system which reveal a declining trend in productivity even with the application of recommended levels of N, P, K fertilizers. Shabeer et al (2015) found that the application of phosphorous a rate of $55 \mathrm{~kg} \mathrm{ha}^{-1}$ for maximizing the chick pea yield.

This study was applied to determine the effect of treflan and phosphorus levels on weeds and yield and it components of chickpea.

\section{MATERIAL AND METHODS}

The experiment was carried out at the research farm of agriculture College- University of DuhokSumail, during spring season 2017, the weather and soil properties are shown in (Table 1). An improved local variety of chick pea was planting in 20/2/2017 and 10/3/2017 in plots $3 \mathrm{~m} \times 1.20 \mathrm{~m}$. The Treflan applied pre-planting (before 10 days) in corporate depth of five $\mathrm{cm}$ in the soil at $5 / 2 / 2017$ and $27 / 2 / 2017$ at $277.5 \mathrm{ml}$ rainfull throw growing season.

The experiment was designed as factorial in Randomize Complete Block Design (RCRD) with 
three replications. The first factor included four dose of treflan herbicide $(0,1.2002 .400$, and 3.600) $\mathrm{L}$ ha-1, and the second factor was four doses of phosphorous $(0,140,180$ and 220) Kg P2O5 ha-1. Each experimental unit (plot) comprised four rows with three meter in length, $0.40 \mathrm{~cm}$ between rows and $0.50 \mathrm{~m}$ between plots. The nitrogen fertilizer was added a rate of $18 \mathrm{Kg}$ ha- 1 with planting For all plots. Weed sampling were done at the flowering of chick pea plants.

The studied weeds traits were number and dry weight of broad and narrow leaved weeds. The weeds dry weight were recorded at $\left(75 c^{0}\right)$ for $(48)$ hr. All data consisted of five plants selected randomly and included plant height, number of primary braches plant ${ }^{-1}$, height of the lowest pod , number of pod plant ${ }^{-1}$, number of seed palnt ${ }^{-1}, 100$ seed weight and seed weight plant $^{-1}$. The data analyzed statistically using Minitab software package (16) and Duncan Multiple Range Test (DMRT) at 5\% level of probability was applied to compare between means. (Steel and torie, 1984).

Table (1): Forecasting and some physical and chemical properties of top $(20-30) \mathrm{cm}$ soil sample of field experiment.

\begin{tabular}{|c|c|c|c|c|c|c|}
\hline \multirow[b]{2}{*}{ Month } & \multicolumn{4}{|c|}{ Weather properties } & \multirow{2}{*}{ soil properties } & \\
\hline & $\begin{array}{l}\text { Ave. Daily } \\
\text { max.tem } c^{0}\end{array}$ & $\begin{array}{l}\text { Ave. Daily } \\
\text { min..tem c } c^{0}\end{array}$ & $\begin{array}{c}\text { Seasonal } \\
\text { Relative } \\
\text { Humidity } \\
\text { RH \% }\end{array}$ & $\begin{array}{c}\text { Seasonal } \\
\text { Rainfall mm }\end{array}$ & & \\
\hline & & 2016 & & & Sand $\left(\mathrm{gkg}^{-1}\right)$ & 89.60 \\
\hline November & 12.1 & 3.6 & 40.9 & 10.2 & Silt $\left(\mathrm{gkg}^{-1}\right)$ & 486.90 \\
\hline December & 11.6 & 2.04 & 79.4 & 72 & Clay $\left(\mathrm{gkg}^{-1}\right)$ & 419.85 \\
\hline & & 2017 & & & Soil texture & Silty clay \\
\hline January & 12.23 & -0.56 & 73.47 & 29.1 & PH in soil past & 8.25 \\
\hline February & 13.76 & -57.2 & 65.8 & 17.6 & $\begin{array}{c}\mathrm{Ec}\left(\mathrm{dsm}^{-1}\right) \text { at } 25 \mathrm{c}^{0} \text { in soil } \\
\text { past }\end{array}$ & 0.55 \\
\hline March & 18.53 & 6.881 & 67.05 & 52.2 & $\mathrm{CaCo} 3\left(\mathrm{~g} \mathrm{~kg}^{-1}\right)$ & 205.2 \\
\hline April & 24.21 & 9.52 & 63.98 & 81.4 & Organic matter $\mathrm{k} \mathrm{ha}^{-1}$ & 145 \\
\hline May & 24.4 & 37.8 & 19 & 15.0 & Available $\mathrm{N} \mathrm{k} \mathrm{ha}^{-1}$ & 0.22 \\
\hline Total & & & & 277.5 & & \\
\hline
\end{tabular}


Table (2): list of broad and narrow leaf weeds in experimental site.

\begin{tabular}{|c|c|c|}
\hline \multicolumn{3}{|c|}{ Broad leaf weeds } \\
\hline Common names & Scientific names & Family names \\
\hline Rough cocklebur & Xanthium strumarium & Copositae \\
\hline Milk thistle & Lactuca serriola $L$. & Copositae \\
\hline Pinkweed & Polygonum aviculare & Polygonaceae \\
\hline Common chicory & Cichorium intybus & Asteraceae \\
\hline Sow thistles & $\underline{\text { Sonchus oleraceus }}$ & Asteraceae \\
\hline$\underline{\text { Saffron Thistle }}$ & Carthamus lanatus & Copositae \\
\hline Centaurea & Centaurea centaurium & Asteraceae \\
\hline Field mustard & Sinapis arvensis & $\underline{\text { Brassicaceae }}$ \\
\hline European heliotrope & Heliotropium europaeum & Boraginaceae \\
\hline Cheeseweed & Malva parviflora & Malvaceae \\
\hline Cephalaria & Cephalaria syriaca $L$. & Caprifoliaceae \\
\hline Convolvulus & Convolvulus arvensis $L$. & Convolvulaceae \\
\hline Cowherb & Vaccaria pyramidata & Coryophyllaceae \\
\hline Puncture vine & Tribulus terrestris $i$ & Zygophyllaceae \\
\hline Fat-hen & Chenopodium album & Amaranthaceae \\
\hline \multicolumn{3}{|c|}{ Narrow leaf weeds } \\
\hline Common names & Scientific names & Family names \\
\hline Wild oat & Avena fatua $L$. & Poaceae \\
\hline Wild barley & Hordeum spontaneum & Poaceae \\
\hline Animated oat & Avena sterilis $L$. & Poaceae \\
\hline Small canary grass & Phalaris minor & Poaceae \\
\hline Hood canary grass & Phalaris paradoxa & Poaceae \\
\hline Beard grass & Polypogon monspeliensis & Poaceae \\
\hline
\end{tabular}




\section{RESULTS AND DISCUSSION}

The statistical analysis of data in the first and second planting dates showed that.the herbicide levels exhibited significant influence on all of traits.(Table 3). The phosphorous level indicated significant effect on all studied traits except the dry weight of narrow leaved weeds and plant height, while the interaction between herbicides and phosphorous level showed considerably effect on the whole traits with the except of plant height and number of primary branches plant ${ }^{-1}$ in the first planting date. In the second planting date the results in the same table exhibited significant effect for herbicide and phosphorous levels and the interaction between them on all studied traits with the exception of plant height. Similar results were also reported by Holmes and Sprague, (2013). who found that the herbicide suppressed weed growth were more efectively than check treatment. 
Table (3):.Mean square analysis of treflan herbicide and phosphor levels on weeds and chick pea yield in first and second planting date.

\begin{tabular}{|c|c|c|c|c|c|c|c|c|c|c|c|c|c|}
\hline \multicolumn{14}{|c|}{ MS } \\
\hline \multicolumn{14}{|c|}{ First planting time } \\
\hline SOV & $d f$ & $\begin{array}{l}\text { No. of broad } \\
\text { leaved } \\
\text { weeds } / \mathrm{m}^{2}\end{array}$ & $\begin{array}{l}\text { Dry weight of } \\
\text { broad leaved } \\
\text { weeds } \mathrm{g} / \mathrm{m}^{2}\end{array}$ & $\begin{array}{c}\text { No. of } \\
\text { narrow } \\
\text { leaved } \\
\text { weeds/ } \\
\mathrm{m}^{2}\end{array}$ & $\begin{array}{l}\text { dry weight of } \\
\text { narrow } \\
\text { leaved } \\
\text { weeds }\left(\mathrm{g} / \mathrm{m}^{2}\right.\end{array}$ & $\begin{array}{l}\text { plant height } \\
\text { (cm) }\end{array}$ & $\begin{array}{c}\text { No. of } \\
\text { primary } \\
\text { branches }^{-1} \\
\text { plant }^{-1}\end{array}$ & $\begin{array}{c}\text { No. of } \\
\text { pods plant }\end{array}$ & $\begin{array}{l}\text { No. of seeds } \\
\text { pod }^{-1}\end{array}$ & $\begin{array}{l}\text { No. Seeds } \\
\text { plant }^{-1} \text { ) }\end{array}$ & $\begin{array}{l}100 \text { grain } \\
\text { weight }(\mathrm{g})\end{array}$ & $\begin{array}{l}\text { Grain weight } \\
\text { plant }^{-1}(\mathrm{~g}\end{array}$ & $\begin{array}{l}\text { Height of the } \\
\text { lowest pod }\end{array}$ \\
\hline Blocks & 2 & 12.58 & $6.4^{*}$ & 0.646 & 168 & 16.46 & 0.009 & 4.15 & 0.006 & 7.73 & 2.436 & 0.097 & 7.084 \\
\hline $\mathrm{H}$ & 3 & $1611.1^{\text {** }}$ & $5948.7^{\star \star}$ & $289.13^{\star \star}$ & $67104^{* \star}$ & $109.32^{* *}$ & $1.85^{\star *}$ & $1348.7^{* *}$ & $0.126^{* *}$ & $2405.8^{\star \star}$ & $241.49^{\star *}$ & $9.0507^{\star \star}$ & $242.4^{\star \star}$ \\
\hline$P$ & 3 & $64.24^{\star \star}$ & $350.4^{* \star}$ & $8.47^{* *}$ & 779 & 14.06 & $0.4 !^{\star \star}$ & $482.55^{\star *}$ & $0.02^{* \star}$ & $479.65^{\star *}$ & $83.403^{\star *}$ & $4.7218^{\star \star}$ & $34.51^{* \star}$ \\
\hline $\mathrm{HxP}$ & 9 & 14.85 & $46.4^{* \star}$ & $2.34^{*}$ & $858^{*}$ & 5.01 & 0.19 & $137.42^{* \star}$ & $0.01^{\star *}$ & $227.3^{\star \star}$ & $20.622^{\star \star}$ & $0.6849^{* \star}$ & $82.9^{* *}$ \\
\hline Error & 30 & 7.98 & 5.6 & 0.89 & 374 & 18.54 & 0.09 & 4.82 & 0.003 & 6.29 & 0.776 & 0.0665 & 4.152 \\
\hline \multicolumn{14}{|c|}{ Second planting time } \\
\hline Block & 2 & 0.271 & 1.15 & 0.2708 & 0.8 & 4.97 & 0.008 & 6.18 & 0.025 & 3.4 & 0.565 & 14.178 & 8.806 \\
\hline $\mathrm{H}$ & 3 & $82.389^{* *}$ & $2449.22^{* \star}$ & $25.91^{* *}$ & $490.3^{* \star}$ & 9.53 & $1.96^{\star *}$ & $783.28^{* *}$ & $0.140^{* *}$ & $1273.2^{* *}$ & $194.94^{* *}$ & $184.04^{* *}$ & $132.02^{* *}$ \\
\hline$P$ & 3 & 2.5 & $93.95^{\star \star}$ & 1.298 & $39.52^{\star \star}$ & 11.73 & $0.520^{\star *}$ & $129.21^{* *}$ & $0.033^{* *}$ & $115.84^{\star \star}$ & $84.635^{\star \star}$ & $86.05^{* *}$ & 6.017 \\
\hline $\mathrm{HxP}$ & 9 & $3.259^{\star \star}$ & $30.96^{\star \star}$ & 0.873 & $21.71^{\star \star}$ & 9.83 & $0.29^{\star \star}$ & $18.41^{* *}$ & $0.020^{* *}$ & $24.39^{\star \star}$ & $17.45^{* \star}$ & 7.73 & $23.497^{\star}$ \\
\hline Error & 30 & 0.938 & 7.69 & 0.4486 & 2.02 & 15.33 & 0.05413 & 3.84 & 0.00530 & 3.53 & 0a.402 & 12.82 & 8.784 \\
\hline Total & 47 & & & & & & & & & & & & \\
\hline
\end{tabular}

*,**, indicating significant difference at 0.05 and 0.01 probability level respectively. $\mathrm{H}-$ Herbicide, P- Phosphorus levels 
The influence of Treflan herbicide levels on (broad and narrow leaved weeds) was significant at different levels (Table 4). The herbicide at both levels of $\mathrm{H} 3$ and $\mathrm{H} 2$ were more efficient when controlled broad leaf weeds with $91 \%$ and $85 \%$, respectively compared to $31 \%$ when use a minimum dose H1. The narrow leaved weeds were controlled with $98 \%$ and $92 \%$ in the first date planting and second date, respectively. However, the herbicide killed broad leaved weeds with $49 \%, 73 \%$, and $85 \%$ when used at $\mathrm{H} 3, \mathrm{H} 2$ and $\mathrm{H} 1$, respectively compared to $41 \%, 73 \%$ and $78 \%$ for narrow leaved weeds. The highest weed control efficacy (91\%) was resulted by $\mathrm{H} 3$ level, fallowed by $\mathrm{H} 2$ For narrow leaved weeds the $\mathrm{H} 3$ level in the first date whereas in the second date of planting the herbicide gave $49 \%, 73 \%, 85 \%$ at $\mathrm{H} 3, \mathrm{H} 2$ and $\mathrm{H} 1$, respectively for broad leaved weeds . the results above, the herbicide provided good weed control in first planting date compared with the second date and this may be due to flatfooted and un favourable climates predominant during second date. was not property table one. For the phosphorus levels the $\mathrm{P}_{0}$ level gave the growth and narrow leaved weed and values were $(13.5,32.1$ $\mathrm{g} / \mathrm{m} 2,6.7$ and $53.9 \mathrm{~g} / \mathrm{m} 2)$ in first planting date while, the same level recorded $(3.2,21.9$ $\mathrm{g} / \mathrm{m} 2,2.7$ and $11.9 \mathrm{~g} / \mathrm{m} 2$ ) in the second planting date. For plant height the $\mathrm{H}_{0}$ level and $\mathrm{P}_{0}$ level gave the tallest plants with values $55.7,53.2 \mathrm{~cm}$, respectively in the first planting date while, the tallest plants in the second planting date observed at $\mathrm{H}_{1}$ and $\mathrm{P}_{2}$ levels because the hight competition between weeds and chick pea plants. Regarding the yield and yield component of chick pea plant, the data in (Table 4). exhibited that the $\mathrm{H}_{3}$ level gave the maximum values $(3.2,43.1$, $1.4,56.4,31.0,6.0$ and $52.0 \mathrm{~cm}$ ) in the first planting date and the same level recorded $(3.1,32.0,1.4,38.5,30.0,4.6$ and $42.3 \mathrm{~cm})$ in the second planting date. For number of primary branches plant $^{-1}$, number of pods plant $^{-1}$, number of seed plant $^{-1}, 100$ grain weight, grain weight plant and height of the lowest pod. For phosphorus levels, the $\mathrm{P}_{3}$ gave the maximum values and recorded (2.8, $34.8,1.3,45.6,5.5$ and 47.6) in the first planting date and same level phosphorous produced the high values $(2.6,24.3,1.3,27.8$, $20.7 \mathrm{~g}, 4.2 \mathrm{~g})$. For number of primary branches plant ${ }^{-1}$, number of pods plant ${ }^{-1}$, number of seed $\operatorname{pod}^{-1}$, seeds plant ${ }^{-1}$, grain weight plant ${ }^{-1}$ in the second planting date. Theses results indicated the best response of chickpea yield and yield components to phosphorus levels as reported by Gebreyeus, (2014).

Table (4):Influence of mean of treflan herbicide and Phosphorus levels on weed and chickpea yield and its components in first and second planting date.

\begin{tabular}{|c|c|c|c|c|c|c|c|c|c|c|c|c|}
\hline $\mathrm{H}$ & $\begin{array}{c}\text { No. of } \\
\text { broad } \\
\text { leaved } \\
\text { weeds/m } \\
2\end{array}$ & $\begin{array}{c}\text { Dry } \\
\text { weight of } \\
\text { broad } \\
\text { leaved } \\
\text { weeds } \\
\mathrm{g} / \mathrm{m}^{2}\end{array}$ & $\begin{array}{c}\text { No. of } \\
\text { narrow } \\
\text { leaved } \\
\text { weeds/m }\end{array}$ & $\begin{array}{c}\text { dry } \\
\text { weight of } \\
\text { narrow } \\
\text { leaved } \\
\text { weeds }(\mathrm{g} / \\
\mathrm{m}^{2}\end{array}$ & $\begin{array}{c}\text { plant } \\
\text { height } \\
(\mathrm{cm})\end{array}$ & $\begin{array}{l}\text { No. of } \\
\text { primary } \\
\text { branch } \\
\text { es } \\
\text { plant }^{-1}\end{array}$ & $\begin{array}{l}\text { No. of } \\
\text { pods } \\
\text { plant }^{-1}\end{array}$ & $\begin{array}{l}\text { No. of } \\
\text { seeds } \\
\text { pod }^{-1}\end{array}$ & $\begin{array}{c}\text { No. } \\
\text { Seeds } \\
\text { plant }^{-1} \text { ) }\end{array}$ & $\begin{array}{c}100 \text { grain } \\
\text { weight }(\mathrm{g})\end{array}$ & $\begin{array}{c}\text { Grain } \\
\text { weight } \\
\text { plant }^{-1} \text { (g }\end{array}$ & $\begin{array}{c}\text { Height } \\
\text { of the } \\
\text { lowest } \\
\text { pod }\end{array}$ \\
\hline \multicolumn{13}{|c|}{ First date } \\
\hline $\mathrm{H}_{0}$ & $27.3 \mathrm{a}$ & $50.8 \mathrm{a}$ & $12.8 \mathrm{a}$ & $155.6 \mathrm{a}$ & $55.7 \mathrm{a}$ & $2.4 \quad b$ & $18.3 \mathrm{~d}$ & $1.2 \quad c$ & $24.3 \mathrm{~d}$ & $20.9 \mathrm{~d}$ & 3.9 & $42.8 \mathrm{~b}$ \\
\hline $\mathrm{H}_{1}$ & $10.9 \mathrm{~b}$ & $35.2 \mathrm{~b}$ & $5.3 \mathrm{~b}$ & $12.9 \mathrm{~b}$ & $51.2 a b$ & $2.5 \quad b$ & 24.5 & $1.2 \mathrm{~b}$ & 29.4 & 24.6 & 4.9 & $42.6 \mathrm{~b}$ \\
\hline $\mathrm{H}_{2}$ & $3.5 \quad c$ & 7.7 & $3.7 \quad c$ & $3.7 \quad b$ & $52.3 \mathrm{ab}$ & $2.3 \quad b$ & $30.9 \quad b$ & $1.2 \quad b c$ & $39.4 \quad b$ & $28.7 \quad b$ & $5.4 \quad b$ & $43.6 \mathrm{~b}$ \\
\hline $\mathrm{H}_{3}$ & $1.9 \quad \mathrm{c}$ & $4.6 \quad d$ & $1.4 \mathrm{~d}$ & $2.4 \quad b$ & $48.4 \quad b$ & $3.2 \mathrm{a}$ & $43.1 \mathrm{a}$ & $1.4 \mathrm{a}$ & $56.4 \mathrm{a}$ & $31.0 \mathrm{a}$ & $6.0 \mathrm{a}$ & $52.0 \mathrm{a}$ \\
\hline $\mathrm{P}_{0}$ & $13.5 \mathrm{a}$ & $32.1 \mathrm{a}$ & $6.7 \mathrm{a}$ & $53.9 \mathrm{a}$ & $53.2 \mathrm{a}$ & $2.4 \quad b$ & $20.7 \quad c$ & $1.2 \quad b$ & $30.7 \quad d$ & $28.6 \mathrm{a}$ & $4.2 \quad c$ & $43.6 \mathrm{~b}$ \\
\hline$P_{1}$ & $12.1 \mathrm{ab}$ & $24.9 \quad b$ & $5.2 \quad b$ & $45.9 \mathrm{a}$ & $52.2 \mathrm{a}$ & $2.6 \mathrm{ab}$ & $28.1 \quad b$ & $1.2 \mathrm{ab}$ & 34.8 & $28.1 \mathrm{a}$ & $5.0 \quad b$ & $44.7 \mathrm{~b}$ \\
\hline $\mathrm{P}_{2}$ & $8.4 \mathrm{c}$ & 21.3 & $4.9 \quad b$ & $39.2 \mathrm{a}$ & $50.6 \mathrm{a}$ & $2.6 \mathrm{ab}$ & $33.1 \mathrm{a}$ & $1.3 \mathrm{a}$ & $38.2 \quad b$ & $25.7 \quad b$ & $5.5 \mathrm{a}$ & $45.1 \mathrm{~b}$ \\
\hline $\mathrm{P}_{3}$ & $9.6 \mathrm{~b} \mathrm{c}$ & 20.0 & $6.3 \mathrm{a}$ & $35.6 \mathrm{a}$ & $51.8 \mathrm{a}$ & $2.8 \mathrm{a}$ & $34.8 \mathrm{a}$ & $1.3 \mathrm{a}$ & $45.6 \mathrm{a}$ & $22.9 \quad \mathrm{c}$ & $5.5 \mathrm{a}$ & $47.6 \mathrm{a}$ \\
\hline
\end{tabular}




\begin{tabular}{|c|c|c|c|c|c|c|c|c|c|c|c|c|c|c|c|c|c|c|c|c|}
\hline $\mathrm{H}_{0}$ & $7.0 \mathrm{a}$ & $37.8 \mathrm{a}$ & & 4.5 & & 17.8 & $a$ & $46.7 \mathrm{a}$ & 2.3 & $\mathrm{~b}$ & $13.8 \mathrm{c}$ & & $1.2 \mathrm{bc}$ & 15.9 & C & 20.50 & & 2.6 & $d$ & $35.4 \mathrm{~b}$ \\
\hline $\mathrm{H}_{1}$ & $2.6 \mathrm{~b}$ & $19.2 \mathrm{~b}$ & & 2.1 & $\mathrm{~b}$ & 10.5 & $\mathrm{~b}$ & $47.7 \mathrm{a}$ & 2.3 & $b$ & $16.7 \mathrm{~b}$ & $\mathrm{~b}$ & 1.1 & 19.8 & $\mathrm{~b}$ & 22.7 & C & 3.2 & C & 37.4 \\
\hline $\mathrm{H}_{2}$ & $1.9 \mathrm{bc}$ & $10.1 \mathrm{c}$ & $\mathrm{c}$ & 1.9 & $\mathrm{~b}$ & 4.8 & C & $45.7 \mathrm{a}$ & 2.3 & $\mathrm{~b}$ & $18.1 \mathrm{~b}$ & b & $1.2 \quad b$ & 19.0 & $\mathrm{~b}$ & 25.0 & $\mathrm{~b}$ & 4.2 & $\mathrm{~b}$ & 35.2 \\
\hline $\mathrm{H}_{3}$ & 1.2 & 5.5 & & 1.1 & C & 3.9 & C & $46.0 \mathrm{a}$ & 3.1 & $a$ & $32.0 \mathrm{a}$ & $\mathrm{a}$ & $1.4 \mathrm{a}$ & 38.5 & $a$ & $30.0 a$ & $a$ & 4.6 & $a$ & $42.3 \mathrm{a}$ \\
\hline $\mathrm{P}_{0}$ & $3.2 \mathrm{a}$ & $21.9 \mathrm{a}$ & $\mathrm{a}$ & 2.7 & $a$ & 11.9 & $a$ & $46.4 \mathrm{a}$ & 2.2 & $\mathrm{~b}$ & 17.0 & C & $1.1 \quad b$ & 20.7 & $\mathrm{~b}$ & $26.7 a$ & $a$ & 2.5 & $\mathrm{C}$ & $36.7 \mathrm{a}$ \\
\hline $\mathrm{P}_{1}$ & $2.5 \mathrm{a}$ & 17.5 & $\mathrm{~b}$ & 2.7 & $a$ & 8.0 & $b$ & $45.5 \mathrm{a}$ & 2.6 & $a$ & 18.2 & C & $1.2 \mathrm{a}$ & 22.3 & $\mathrm{~b}$ & 25.9 & $\mathrm{~b}$ & 3.8 & $\mathrm{~b}$ & $37.8 \mathrm{a}$ \\
\hline $\mathrm{P}_{2}$ & $3.5 \mathrm{a}$ & 18.0 & $\mathrm{~b}$ & 2.3 & $a$ & 8.4 & $b$ & $47.9 \mathrm{a}$ & 2.6 & $a$ & 21.2 & $\mathrm{~b}$ & $1.2 \mathrm{ab}$ & 22.4 & $b$ & 24.9 & C & 4.1 & $a$ & $38.3 \mathrm{a}$ \\
\hline $\mathrm{P}_{3}$ & $3.4 \mathrm{a}$ & 15.2 & $\mathrm{~b}$ & 2.0 & $a$ & 8.7 & $\mathrm{~b}$ & $46.3 \mathrm{a}$ & 2.6 & $a$ & $24.3 \mathrm{a}$ & $\bar{a}$ & $1.3 \mathrm{a}$ & 27.8 & $a$ & 20.7 & $d$ & 4.2 & $a$ & $37.4 \mathrm{a}$ \\
\hline
\end{tabular}

Means in each column followed by the same letter are not significantly different at the 5\% probability level according to Duncan's Multiple Range Test.

Results in the Table (5) condiment that $\mathrm{H} 3$ and P3 were superior in all studied traits which gave minimum values for number and dry weight of broad and narrow leaved weeds and recorded values $(1.0,2.5 \mathrm{~g}, 1.3$ and1.2g), respectively compared witcheck treatment for plant height while the same interaction of $\mathrm{P} 3$ produced the highest plant with $58.3 \mathrm{~cm}$. The interaction $\mathrm{H}_{3} \mathrm{x}$ $\mathrm{P}_{3}$ level gave the highest values $(3.6,54.7,1.5$, $76.4,34.3 \mathrm{~g}$ and for number of primary branches plant ${ }^{-1}$, pods plant ${ }^{-1}$, sees pod ${ }^{-1}$, seeds plant, 100grain weight and grain weight plant $^{-1}$, respectively in the first planting date. In the second planting date also, the $\mathrm{H}_{3} \mathrm{P}_{3}$ showed superiority of number and dry weight of broad and narrow leaved weeds and gave minimum values compare with check treatment $\left(\mathrm{H}_{0} \mathrm{P}_{0}\right)$, while, the yield and yield component recorded the maximum values (3.6, $40.0,46.3,34.6 \mathrm{~g}$ and $5.7 \mathrm{~g}$ ) for number of primary branches plant ${ }^{-1}$, pods plant ${ }^{-1}$. Regarding to height of the lowest pod the $\mathrm{H}_{0} \mathrm{P}_{0}$ level gave the highest value $(57.4 \mathrm{~cm})$ in the first planting date, while the $\mathrm{H}_{3} \mathrm{P}_{1}$ recorded the maximum value (45.5 $\mathrm{cm})$. It can be concluded from the above results that the herbicide and phosphorous levels $\left(\mathrm{H}_{3} \mathrm{P}_{3}\right)$ is the most effective to kill weed and increasing yield and yield component. These results are in agreement with those of Muhammad et al. (2010). 
Table (5): Influence of treflan herbicide and Phosphorus levels on weed and chickpea yield in first and second planting date.

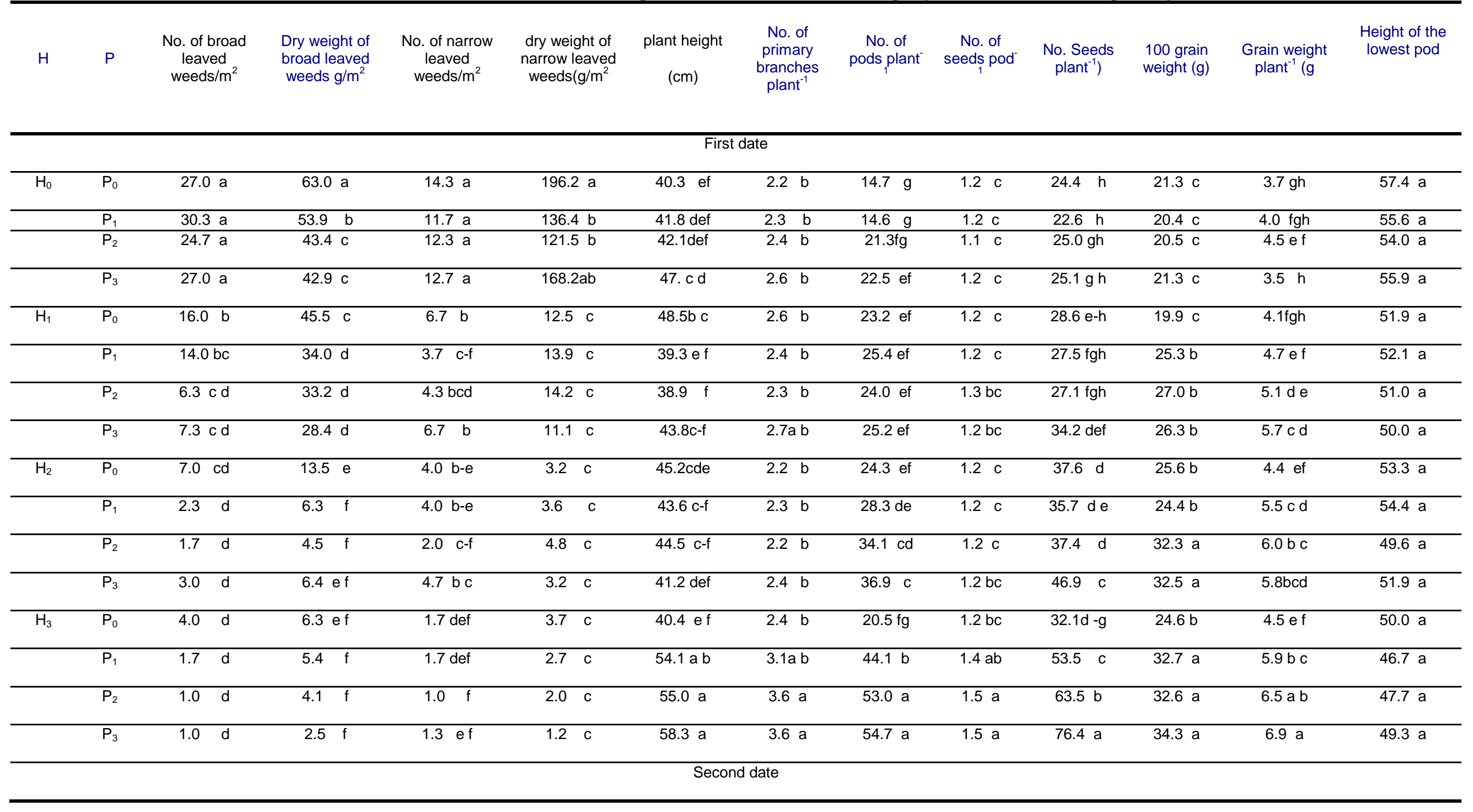


Journal of University of Duhok., Vol. 20, No.1 (Agri. and Vet. Sciences), Pp 87-104, 2017

DOI: https://doi.org/10.26682/avuod.2017.20.1.11

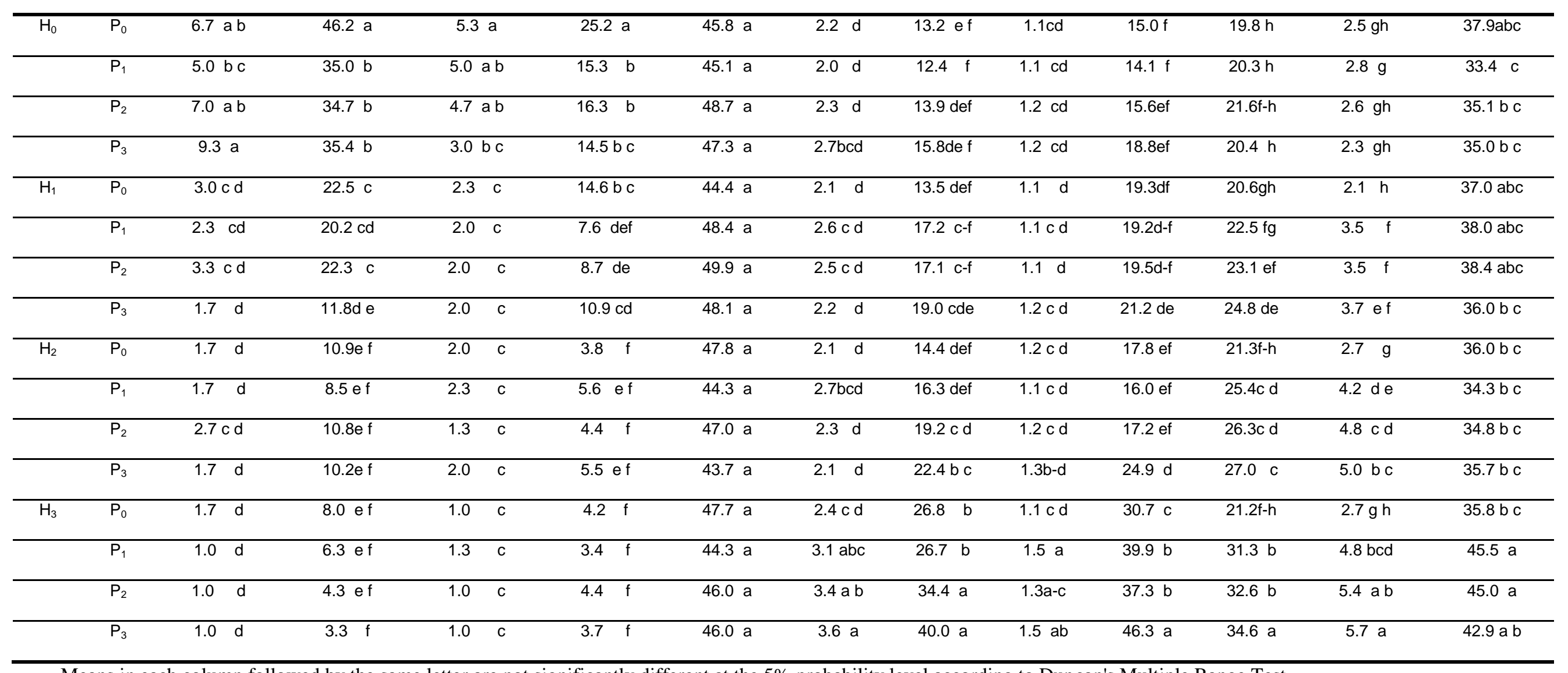

Means in each column followed by the same letter are not significantly different at the 5\% probability level according to Duncan's Multiple Range Test. 
Table (6) shows the analysis of triple interaction between treflan herbicide , phosphorus levels and planting date on weeds and chickpea yield in both of plating dates. The results exhibited significant effect of herbicide level in the whole traits. Also the phosphorus level produced considerably effect with the exception of plant height and number of branches plant ${ }^{-1}$. The planting dates gave remarkably effect on the whole of studied traits. According to the means square values the results showed that the interaction between herbicide and phosphorus levels resulted significant effect on all examined traits except plant height and number of branches plant ${ }^{-1}$ nevertheless the interaction between herbicide and planting date was realized significant effect studied traits. The interaction between phosphorus and planting date gave partia effect on examined traits with the except of dry weight of narrow leaved weeds, number of primary branches plant ${ }^{-1}$, seeds pod $^{-1}$ and height of the lowest pod. The trill interaction between herbicide, phosphorus and planting dates produced significant effect on studied traits except number of broad leaved weeds, dry weight of narrow leaved weeds, plant height and number of primary branches plant ${ }^{-1}$. These results were in agreement with the results proved by Kumar and Sreenivasvly, (2004) . and Mahajan and Sharma, (2005).

Table (6): Combined analysis of treflan herbicide and phosphorus application on weeds and chickpea yield

\begin{tabular}{|c|c|c|c|c|c|c|c|c|c|c|c|c|c|}
\hline \multirow[b]{2}{*}{ S.O.V } & \multirow[b]{2}{*}{$d f$} & \multicolumn{11}{|c|}{ MS } & \multirow[b]{2}{*}{$\begin{array}{l}\text { Height of the } \\
\text { lowest pod }\end{array}$} \\
\hline & & $\begin{array}{c}\text { No. of broad } \\
\text { leaved } \\
\text { weeds } / \mathrm{m}^{2}\end{array}$ & $\begin{array}{l}\text { Dry weight of } \\
\text { broad leaved } \\
\text { weeds } \mathrm{g} / \mathrm{m}^{2}\end{array}$ & $\begin{array}{c}\text { No. of narrow } \\
\text { leaved } \\
\text { weeds } / \mathrm{m}^{2}\end{array}$ & $\begin{array}{l}\text { dry weight of } \\
\text { narrow } \\
\text { leaved } \\
\text { weeds }\left(\mathrm{g} / \mathrm{m}^{2}\right.\end{array}$ & $\begin{array}{l}\text { plant } \\
\text { height } \\
(\mathrm{cm})\end{array}$ & $\begin{array}{c}\text { No. of } \\
\text { primary } \\
\text { branches } \\
\text { plant }^{-1}\end{array}$ & $\begin{array}{l}\text { No. of } \\
\text { pods } \\
\text { plant }^{-1}\end{array}$ & $\begin{array}{l}\text { No. of } \\
\text { seeds } \\
\text { pod }^{-1}\end{array}$ & $\begin{array}{l}\text { No. Seeds } \\
\text { plant }^{-1} \text { ) }\end{array}$ & $\begin{array}{l}100 \text { grain } \\
\text { weight }(\mathrm{g})\end{array}$ & $\begin{array}{l}\text { Grain weight } \\
\text { plant }^{-1}(\mathrm{~g}\end{array}$ & \\
\hline block & 2 & $\underset{*}{4.59}$ & 1.89 & $\underset{*}{0.125}$ & $\underset{*}{73.6}$ & 2.21 & $142.72^{* *}$ & 2.09 & $\underset{\star \star}{0.44}$ & 0.026 & $\underset{*}{2.19}$ & 0.07 & $\underset{*}{5.98}$ \\
\hline $\mathrm{H}$ & 3 & $1206.3^{\star *}$ & $\underset{* *}{7861.9}$ & $243.70^{\star *}$ & 39068.** & $\underset{*}{65.27}$ & $\underset{*}{55.29}$ & $2050.0^{\star *}$ & 3464 & 0.251 & $423.68^{* *}$ & $\underset{* *}{19.18}$ & $353.61^{* *}$ \\
\hline$P$ & 3 & $\begin{array}{c}26.45 \\
* *\end{array}$ & $\underset{* *}{389.86}$ & $\underset{* *}{4.899}$ & $\underset{*}{563.3}$ & 3.87 & 0.28 & $531.81^{* *}$ & $\underset{* *}{523.2}$ & $\underset{* *}{0.050}$ & $\underset{* *}{165.5}$ & 11.79 & $23.72^{*}$ \\
\hline $\mathrm{T}$ & 1 & $1433.8^{\star *}$ & $\underset{* *}{983.94}$ & $276.76^{\star \star}$ & $28400 .^{* *}$ & $\underset{\star \star \star}{697.8}$ & $152.01^{\star *}$ & $1958.7^{\star \star}$ & $\begin{array}{c}4732 \\
.^{* *}\end{array}$ & $\underset{* *}{0.031}$ & $\underset{* \star}{75.26}$ & $\underset{* *}{46.97}$ & $1426.0^{* *}$ \\
\hline $\mathrm{H} \times \mathrm{P}$ & 9 & $\underset{*}{9.39}$ & $\underset{* *}{58.55}$ & $\underset{* \star}{2.464}$ & 505.1 & 8.69 & 3.29 & $105.71^{* *}$ & $\underset{* *}{186.8}$ & 0.021 & $\underset{\star *}{29.65}$ & $\underset{* *}{1.59}$ & $78.38^{* *}$ \\
\hline $\mathrm{H} \times \mathrm{T}$ & 3 & $487.23^{* *}$ & 536 & $71.344^{* *}$ & 28526 & $\underset{\star}{53.58}$ & $\underset{\star}{70.7}$ & $\underset{* *}{81.98}$ & $\underset{*}{214.61}$ & $\underset{* \star}{0.015}$ & $\underset{\star *}{12.76}$ & 0.24 & $\underset{*}{20.8}$ \\
\hline$P \times T$ & 3 & $\underset{* \star}{40.29}$ & $\underset{* \star}{54.5}$ & $\underset{* *}{4.872}$ & 255.5 & $\underset{*}{21.93}$ & 1.64 & $\underset{* *}{79.95}$ & 72.24 & $\underset{* *}{0.003}$ & $\underset{* *}{2.52}$ & $\underset{* *}{0.28}$ & 16.81 \\
\hline $\mathrm{H} \times \mathrm{P} \times \mathrm{T}$ & 9 & 8.72 & $\underset{* *}{18.76}$ & $\underset{*}{0.751}$ & 374.1 & 6.15 & 2.66 & $\underset{* \star}{50.12}$ & $\underset{*}{64.84}$ & $\underset{* \star}{0.009}$ & $\underset{* *}{8.43}$ & $\underset{\star \star}{0.19}$ & $28.04^{* *}$ \\
\hline Error & 62 & 4.58 & 6.62 & 0.673 & 185.2 & 17.01 & 19.55 & 4.46 & 5.1 & 0.004 & 0.60 & 0.05 & 6.58 \\
\hline Total & 95 & & & & & & & & & & 2.19 & & 5.98 \\
\hline
\end{tabular}

**, indicating significant difference at 0.05 and 0.01 probability level respectively. $\mathrm{H}-$ Herbicide, P- Phosphor levels. T- Planting time 
Table 7. Exhibited the effect of each of treflan herbicide, phosphorous levels and planting dates on studied characters. that the check treatment gave the maximum values for number and dry weight of broad and narrow leaved weight compared with $\mathrm{H} 3$ level and recoded 17.1, $44.3 \mathrm{~g}$, 8.6 and $86.7 \mathrm{~g}$. While, the $\mathrm{H} 3$ level record the lowest values for all mentioned traits and the values were $1.5,5 \mathrm{~g}, 1.3$ and 3.2. Concerning yield and yield component, the $\mathrm{H} 3$ level perceived the maximum values(37.5, 1.4, 47.5,30.5 g, 5.3g and $47.1 \mathrm{~cm}$ for number of pod plant-1, seed pod-1, seeds plant-1, 100-grain weight, grain yield plant1 and height of the lowest pod, respectively. Thus the herbicide (H3 level) was effective to play a role and killed far of broad and narrow leaved eweds. Regarding the phosphorous level the table
7 realized that the $\mathrm{P}_{3}$ level gave the highest value for yield and yield component of chickpea and the same level recorded $(3.8,29.6,1.3,36.7,27.7 \mathrm{~g}$ ,4.8 and 42.5) for each of number of primary branches plant, pods plant ${ }^{-1}$, seeds pod $^{-1}$, seeds plant $^{-1}$, 100-grain weight, grain yield per plant and height of the lowest pod, respectively. According to results in the Table (7) the second planting date recorded the lowest values for number and dry weight of broad and narrow leaved weeds, whereas the first planting date was worthily significant for yield and yield component compared with the second planting date, this means the first planting date was appropriate for growth the chickpea plant. Similar trends were found by Yadav, (1988) and Bhallq etal., (1998).

Table (7): Effect of herbicide, phosphorus levels and planting date separately on weed and chickpea yield.

\begin{tabular}{|c|c|c|c|c|c|c|c|c|c|c|c|c|}
\hline & $\begin{array}{l}\text { No. of } \\
\text { broad } \\
\text { leaved } \\
\text { weeds } \\
/ \mathrm{m}^{2}\end{array}$ & $\begin{array}{c}\text { Dry } \\
\text { weight } \\
\text { of } \\
\text { broad } \\
\text { leaved } \\
\text { weeds } \\
\mathrm{g} / \mathrm{m}^{2}\end{array}$ & $\begin{array}{c}\text { No. of } \\
\text { narrow } \\
\text { leaved } \\
\text { weeds/ } \\
\mathrm{m}^{2}\end{array}$ & $\begin{array}{c}\text { dry } \\
\text { weight } \\
\text { of } \\
\text { narro } \\
\text { w } \\
\text { leaved } \\
\text { weeds } \\
\left(\mathrm{g} / \mathrm{m}^{2}\right.\end{array}$ & $\begin{array}{l}\text { plant } \\
\text { height } \\
(\mathrm{cm})\end{array}$ & $\begin{array}{l}\text { No. of } \\
\text { primary } \\
\text { branch } \\
\text { es } \\
\text { plant }^{-1}\end{array}$ & $\begin{array}{l}\text { No. of } \\
\text { pods } \\
\text { plant }^{-1}\end{array}$ & $\begin{array}{l}\text { No. of } \\
\text { seeds } \\
\text { pod }^{-1}\end{array}$ & $\begin{array}{c}\text { No. } \\
\text { Seeds } \\
\text { plant }^{-1} \text { ) }\end{array}$ & $\begin{array}{c}100 \\
\text { grain } \\
\text { weight } \\
\text { (g) }\end{array}$ & $\begin{array}{l}\text { Grain } \\
\text { weight } \\
\text { plant }^{-1} \\
\text { (g }\end{array}$ & $\begin{array}{c}\text { Height } \\
\text { of the } \\
\text { lowest } \\
\text { pod }\end{array}$ \\
\hline $\mathrm{H}_{0}$ & $17.1 a$ & $44.3 \mathrm{a}$ & 8.6 a & 86.7 a & $51.2 \mathrm{a}$ & 5.9 a & $16.1 \mathrm{~d}$ & $1.2 \mathrm{~b}$ & $20.1 d$ & $20.7 d$ & $3.3 \mathrm{~d}$ & $39.1 \mathrm{~b}$ \\
\hline $\mathrm{H}_{1}$ & $6.8 b$ & $27.2 b$ & $3.7 \mathrm{~b}$ & $11.7 \mathrm{~b}$ & $49.5 \mathrm{ab}$ & $3.8 \mathrm{a} \mathrm{b}$ & 20.6 c & $1.2 \mathrm{~b}$ & $24.6 \mathrm{c}$ & $23.7 \mathrm{c}$ & 4.1 & $40.0 \mathrm{~b}$ \\
\hline $\mathrm{H}_{2}$ & $2.7 \mathrm{c}$ & $8.9 \mathrm{c}$ & $2.8 \mathrm{c}$ & $4.2 \mathrm{~b}$ & 49.0 a b & $2.5 \mathrm{~b}$ & $24.5 \mathrm{~b}$ & $1.2 \mathrm{~b}$ & $29.2 \mathrm{~b}$ & $26.8 b$ & 4.8 & $39.4 \quad b$ \\
\hline $\mathrm{H}_{3}$ & $1.5 \mathrm{c}$ & $5.0 \mathrm{~d}$ & $1.3 \mathrm{~d}$ & $3.2 \mathrm{~b}$ & $47.2 \quad b$ & $2.9 \mathrm{a} \mathrm{b}$ & 37.5 a & $1.4 \mathrm{a}$ & $47.5 \mathrm{a}$ & 30.5 a & $5.3 \mathrm{a}$ & $47.1 \mathrm{a}$ \\
\hline $\mathrm{N}_{0}$ & $8.4 \mathrm{a}$ & $27.0 \mathrm{a}$ & $4.7 \mathrm{a}$ & 32.9 a & 49.8 a & 3.8 & $18.8 \mathrm{~d}$ & $1.2 \mathrm{~b}$ & $25.7 \mathrm{~d}$ & $21.8 \mathrm{~d}$ & 3.3 & $40.1 \quad b$ \\
\hline $\mathrm{N}_{1}$ & $7.3 \mathrm{ab}$ & $21.2 \mathrm{~b}$ & $4.0 \quad \mathrm{~b}$ & $27.3 \mathrm{ab}$ & 48.9 a & 3.9 & $23.1 \mathrm{c}$ & $1.2 \mathrm{a}$ & $28.6 \mathrm{c}$ & 25.3 & $4.4 \quad b$ & $41.3 \mathrm{ab}$ \\
\hline $\mathrm{N}_{2}$ & $6.0 \mathrm{~b}$ & $19.7 \mathrm{~b}$ & $3.6 \mathrm{~b}$ & $23.6 \mathrm{ab}$ & $49.2 \mathrm{a}$ & 3.6 & $27.1 \quad b$ & $1.2 \mathrm{a}$ & $30.3 \mathrm{~b}$ & $27.0 \quad b$ & 4.8 & $41.7 \mathrm{ab}$ \\
\hline $\mathrm{N}_{3}$ & $6.5 \mathrm{~b}$ & $17.6 \mathrm{c}$ & $4.2 \mathrm{ab}$ & $22.0 \quad b$ & $49.0 \mathrm{a}$ & 3.8 & 29.6 a & $1.3 \mathrm{a}$ & 36.7 a & 27.7 & 4.8 & 42.5 \\
\hline $\mathrm{D}_{1}$ & $10.9 \mathrm{a}$ & 24.6 a & $5.8 \mathrm{a}$ & $43.7 \mathrm{a}$ & 51.9 a & $5.0 \quad \mathrm{a}$ & $29.2 \mathrm{a}$ & $1.2 \mathrm{a}$ & $37.3 \mathrm{a}$ & $26.3 \mathrm{a}$ & $5.1 \mathrm{a}$ & $45.3 \mathrm{a}$ \\
\hline $\mathrm{D}_{2}$ & $3.2 \mathrm{~b}$ & $18.2 \mathrm{~b}$ & $2.4 \quad b$ & $9.3 \mathrm{~b}$ & $46.5 \mathrm{~b}$ & $2.5 \mathrm{~b}$ & $20.2 \mathrm{~b}$ & $1.2 \mathrm{~b}$ & $23.3 \mathrm{~b}$ & $24.5 \mathrm{~b}$ & 3.7 & 37.6 \\
\hline
\end{tabular}

Means in each column followed by the same letter are not significantly different at the 5\% probability level according to Duncan's Multiple Range Test. 
Table (8) clarified the interaction effect between treflan herbicide and phosphorous levels on weed and chickpea yield as mean of both planting dates. We can notice the total of three levels of herbicide were tested for weed control in chick pea, the efficiency of herbicide level was rated in comparison with control as 97 and $99 \%$ for broad and narrow leaved weeds, respectively. The results revealed that differences due to different herbicide levels were found nonsignificant with regard to number and dry weight of broad and narrow leaved weeds. In general, the maximum number and dry weight were observed under check treatment. Furtherhore, plant height and number of primary plant ${ }^{-1}$ of chickpea was also found non-significant due to the interaction between herbicide and phosphorus levels. Number of seeds pod $^{-1}$, seeds plant ${ }^{-1}$, 100-grain weight, grain yield plant ${ }^{-1}$ and height of lowest pod were significantly influenced due to interaction between herbicide and phosphorous levels and $\mathrm{H}_{3}$ level was found superior and registered higher values for above traits as compare to all other treatments and the values which were $1.5,61.3,34.5 \mathrm{~g}, 6.3 \mathrm{~g}$ and 50.6 consequence. The maximum number of pod plant $^{-1}$, seeds pod $^{-1}$, 100-grain weight, grain weight plant and height of the lowest pod under above said treatment might be duo to effective control of weed at critical crop-weed competition stages, which might have helped in increasing nutrient formation of bold seeds, and consequently increase in the above traits. Similar results were also reported by Upadhyay and Bhalla (2002).

Table (8). Interaction effect between treflan herbicide and phosphorus levels on weeds and chickpea yield as average of both planting dates.

\begin{tabular}{|c|c|c|c|c|c|c|c|c|c|c|c|c|c|}
\hline $\mathrm{H}$ & $\mathrm{P}$ & $\begin{array}{c}\text { No. of } \\
\text { broad } \\
\text { leaved } \\
\text { weeds/ } \\
\mathrm{m}^{2}\end{array}$ & $\begin{array}{c}\text { Dry } \\
\text { weight } \\
\text { of broad } \\
\text { leaved } \\
\text { weeds } \\
\mathrm{g} / \mathrm{m}^{2}\end{array}$ & $\begin{array}{c}\text { No. of } \\
\text { narrow } \\
\text { leaved } \\
\text { weeds/ } \\
\mathrm{m}^{2}\end{array}$ & $\begin{array}{c}\text { dry } \\
\text { weight } \\
\text { of } \\
\text { narrow } \\
\text { leaved } \\
\text { weeds( } \\
\mathrm{g} / \mathrm{m}^{2}\end{array}$ & $\begin{array}{l}\text { plant } \\
\text { height } \\
(\mathrm{cm})\end{array}$ & $\begin{array}{c}\text { No. of } \\
\text { primary } \\
\text { branches } \\
\text { plant }^{-1}\end{array}$ & $\begin{array}{c}\text { No. of } \\
\text { pods plant }\end{array}$ & $\begin{array}{l}\text { No. of } \\
\text { seeds } \\
\text { pod }^{-1}\end{array}$ & $\begin{array}{c}\text { No. } \\
\text { Seeds } \\
\text { plant }^{-1} \text { ) }\end{array}$ & $\begin{array}{c}100 \\
\text { grain } \\
\text { weight } \\
\text { (g) }\end{array}$ & $\begin{array}{l}\text { Grain } \\
\text { weight } \\
\text { plant }^{-1} \\
\text { (g }\end{array}$ & $\begin{array}{c}\text { Height } \\
\text { of the } \\
\text { lowest } \\
\text { pod }\end{array}$ \\
\hline \multirow{4}{*}{$\mathrm{H}_{0}$} & $p_{0}$ & $16.8 \mathrm{a}$ & $54.6 \quad \mathrm{a}$ & $9.8 \mathrm{a}$ & $110.7 \mathrm{a}$ & $51.6 \mathrm{a}$ & $4.9 \mathrm{a}$ & $13.9 \mathrm{~h}$ & $1.2 \mathrm{~b}$ & $19.7 \mathrm{~g} \mathrm{~h}$ & $20.6 \mathrm{~h}$ & $3.1 \mathrm{~g} \mathrm{~h}$ & $39.1 \mathrm{~b}$ \\
\hline & $p_{1}$ & $17.7 \mathrm{a}$ & $44.4 b$ & $8.3 \mathrm{ab}$ & $75.8 \mathrm{~b}$ & $50.3 \mathrm{a}$ & $5.7 \mathrm{a}$ & $13.5 \quad h$ & $1.2 \quad b$ & $18.3 \mathrm{~h}$ & $20.4 \mathrm{~h}$ & $3.4 \mathrm{fg}$ & $37.6 \mathrm{~b}$ \\
\hline & $p_{2}$ & $15.8 \mathrm{a}$ & $39.1 \mathrm{c}$ & $8.5 \mathrm{ab}$ & $68.9 \mathrm{~b}$ & $51.3 \mathrm{a}$ & $6.2 \mathrm{a}$ & $17.6 \mathrm{~g} \mathrm{~h}$ & $1.2 \mathrm{~b}$ & $20.3 \mathrm{gh}$ & $21.1 \mathrm{~h}$ & $3.6 f$ & $38.6 \mathrm{~b}$ \\
\hline & $\mathrm{p}_{3}$ & $18.2 \mathrm{a}$ & $39.1 \quad c$ & $7.8 \quad b$ & $91.4 a b$ & $51.6 \mathrm{a}$ & $6.7 \mathrm{a}$ & $19.2 \mathrm{fg}$ & $1.2 \quad b$ & $21.9 f g h$ & $20.9 h$ & $2.9 \mathrm{~h}$ & $41.1 \mathrm{~b}$ \\
\hline \multirow{4}{*}{$\mathrm{H}_{1}$} & $p_{0}$ & $9.5 \quad b$ & $34.0 \mathrm{c}$ & $4.5 \quad c$ & $13.5 \mathrm{c}$ & $48.2 \mathrm{a}$ & $4.4 \mathrm{a}$ & $18.4 \mathrm{fg}$ & $1.1 \quad b$ & 24.0efg & $20.3 \mathrm{~h}$ & $3.1 \mathrm{gh}$ & $42.7 \mathrm{~b}$ \\
\hline & $p_{1}$ & $8.2 \mathrm{~b} \mathrm{c}$ & $27.1 \mathrm{~d}$ & $2.8 c-g$ & $10.8 \mathrm{c}$ & $50.2 \mathrm{a}$ & $4.7 \mathrm{a}$ & 21.3 efg & $1.2 \quad b$ & 23.4efg & 23.9efg & $4.1 \mathrm{e}$ & $38.7 b$ \\
\hline & $p_{2}$ & $4.8 \mathrm{~cd}$ & $27.7 \mathrm{~d}$ & 3.2 cde & $11.5 \mathrm{c}$ & $50.4 \mathrm{a}$ & $3.2 \mathrm{a}$ & 20.6 efg & $1.2 \quad b$ & 23.3efg & $25.1 \mathrm{de}$ & $4.3 \mathrm{de}$ & $38.6 \mathrm{~b}$ \\
\hline & $p_{3}$ & $4.5 \mathrm{~cd}$ & 20.1 e & $4.3 \quad c$ & $11.0 \mathrm{c}$ & $49.0 \mathrm{a}$ & $3.0 \mathrm{a}$ & 22.1 ef & $1.2 \quad b$ & $27.7 \mathrm{de}$ & $25.5 \mathrm{~d}$ & $4.7 \mathrm{~cd}$ & $39.9 \mathrm{~b}$ \\
\hline \multirow{4}{*}{$\mathrm{H}_{2}$} & $\mathrm{p}_{0}$ & $4.3 \mathrm{~cd}$ & $12.2 \mathrm{f}$ & $3.0 \mathrm{c}-\mathrm{f}$ & 3.5 & $50.5 \mathrm{a}$ & $3.2 \mathrm{a}$ & 19.4 efg & $1.2 \quad b$ & $27.7 \mathrm{de}$ & $23.4 \mathrm{fg}$ & $3.6 \mathrm{fg}$ & $40.6 \mathrm{~b}$ \\
\hline & $p_{1}$ & $2.0 \mathrm{~d}$ & $7.4 \mathrm{fgh}$ & 3.2 cde & 4.6 & $49.4 \mathrm{a}$ & $2.5 \mathrm{a}$ & $22.3 \mathrm{def}$ & $1.2 \quad b$ & 25.9 ef & 24.9def & $4.8 \mathrm{c}$ & $39.0 \mathrm{~b}$ \\
\hline & $p_{2}$ & $2.2 d$ & $7.6 \mathrm{fgh}$ & $1.7 \mathrm{~d}-\mathrm{h}$ & 4.6 & $48.3 \mathrm{a}$ & $2.1 \mathrm{a}$ & $26.7 \mathrm{~cd}$ & $1.2 \quad b$ & $27.3 \mathrm{de}$ & $29.3 \mathrm{c}$ & $5.4 \quad b$ & $39.6 \mathrm{~b}$ \\
\hline & $p_{3}$ & $2.3 \quad d$ & $8.3 \mathrm{fg}$ & $3.3 \mathrm{~cd}$ & 4.4 & $47.8 \mathrm{a}$ & $2.2 \mathrm{a}$ & $29.7 \quad c$ & $1.2 \quad b$ & $35.9 \quad c$ & $29.7 \quad c$ & $5.4 \quad b$ & $38.5 \mathrm{~b}$ \\
\hline \multirow{4}{*}{$\mathrm{H}_{3}$} & $p_{0}$ & $2.8 \mathrm{~d}$ & $7.2 \mathrm{fgh}$ & $1.3 \mathrm{fgh}$ & 4.0 & $48.8 \mathrm{a}$ & $2.7 \mathrm{a}$ & $23.7 \mathrm{~d} \mathrm{e}$ & $1.2 \quad b$ & $31.4 \mathrm{~cd}$ & $22.9 \mathrm{~g}$ & $3.6 f$ & $38.1 \mathrm{~b}$ \\
\hline & $p_{1}$ & $1.3 \mathrm{~d}$ & $5.8 \mathrm{gh}$ & $1.5 \mathrm{eh}$ & 3.0 & $45.5 \mathrm{a}$ & $2.7 \mathrm{a}$ & $35.4 \quad b$ & $1.4 \quad \mathrm{a}$ & $46.7 \quad b$ & $32.0 \mathrm{~b}$ & $5.4 \quad b$ & $49.8 \mathrm{a}$ \\
\hline & $\mathrm{p}_{2}$ & $1.0 \mathrm{~d}$ & $4.2 \mathrm{gh}$ & $1.0 \mathrm{~h}$ & 3.2 & $46.9 \mathrm{a}$ & $3.0 \mathrm{a}$ & $43.7 \mathrm{a}$ & $1.4 \quad \mathrm{a}$ & $50.4 \quad b$ & $32.6 \quad b$ & $6.0 \mathrm{a}$ & $50.0 \mathrm{a}$ \\
\hline & $p_{3}$ & $1.0 \mathrm{~d}$ & $2.9 \mathrm{~h}$ & $1.2 \mathrm{~g} \mathrm{~h}$ & $2.4 \quad c$ & $47.7 \mathrm{a}$ & $3.2 \mathrm{a}$ & $47.3 \mathrm{a}$ & $1.5 \quad \mathrm{a}$ & $61.3 \mathrm{a}$ & $34.5 \mathrm{a}$ & $6.3 \mathrm{a}$ & $50.6 \mathrm{a}$ \\
\hline
\end{tabular}


Means in each column followed by the same letter are not significantly different at the 5\% probability level according to Duncan's Multiple Range Test.

The data in table 9. described an interaction effect between each of treflan herbicide ,phosphorus levels with planting dates. The check treatment in first date was superior in number and dry weight of broad and narrow leaved weeds and recorded 27.2, $50.8 \mathrm{~g}, 12.8$ and $55.6 \mathrm{~g}$ while, the $\mathrm{H}_{3}$ level in second date of planting remarked the highest values for above traits and perceived 12.0, $4.6 \mathrm{~g}, 1.1$, and 2.4, respectively. For plant height and number of branches plant ${ }^{-1}$ recognized the highest values obtained by check treatment in first planting date, the values were $55.6 \mathrm{~cm}$ and 55.7 . Regarding yield and yield components the $\mathrm{H}_{3}$ level in first planting date realized the maximum values $(43.1,56,4,31.0 \mathrm{~g}, 6.0 \mathrm{~g}$, and $52.0 \mathrm{~cm}$ for number of pod plant ${ }^{-1}$, seeds plant ${ }^{-1}, 100$ - grain weight, grain weight plant ${ }^{-1}$ and height of the lowest pod, respectively. The results showed that the $\mathrm{P}_{0}$ level in first planting date gave the maximum values $(13.5,32.1 \mathrm{~g}, 6.7$ and $58.9 \mathrm{~g}$, $53.2 \mathrm{~cm}$ )., for number and dry weight of broad and narrow leaved weeds and plant height respectively, as . Whereas, the $\mathrm{P}_{3}$ level in first planting date recorded the highest values (34.8, 1.3, 45.6, $28.6 \mathrm{~g}$ and $47.6 \mathrm{~cm}$. for number of pods plant $^{-1}$, seeds pod $^{-1}$, seeds plant $^{-1}$, 100-grain weight, grain weight plant $^{-1}$ and height of the lowest pod.

The highest density and dry weight of weeds were produced by control treatment as compared to rest of treatments. All herbicide and phosphorus levels gave a good indicator to increase yield and yield components and reduced in the number of broad and narrow leaved weeds. The results Compatible with (Thorat 2004 and Patel et al 2006).

Table( 9): Interaction effect between each of treflan herbicide and phosphorus levels with planting date on weeds and chickpea yield .

\begin{tabular}{|c|c|c|c|c|c|c|c|c|c|c|c|c|c|}
\hline $\mathrm{H}$ & $\mathrm{D}$ & $\begin{array}{l}\text { No. of } \\
\text { broad } \\
\text { leaved } \\
\text { weeds/ } \\
\mathrm{m}^{2}\end{array}$ & $\begin{array}{c}\text { Dry } \\
\text { weight of } \\
\text { broad } \\
\text { leaved } \\
\text { weeds } \\
\mathrm{g} / \mathrm{m}^{2}\end{array}$ & $\begin{array}{c}\text { No. of } \\
\text { narrow } \\
\text { leaved } \\
\text { weeds/m² }\end{array}$ & $\begin{array}{c}\text { dry } \\
\text { weight of } \\
\text { narrow } \\
\text { leaved } \\
\text { weeds }(\mathrm{g} / \\
\mathrm{m}^{2}\end{array}$ & $\begin{array}{l}\text { plant } \\
\text { height } \\
(\mathrm{cm})\end{array}$ & $\begin{array}{c}\text { No. of } \\
\text { primary } \\
\text { branches } \\
\text { plant }^{-1}\end{array}$ & $\begin{array}{l}\text { No. of } \\
\text { pods } \\
\text { plant }^{-1}\end{array}$ & $\begin{array}{l}\text { No. of } \\
\text { seeds } \\
\text { pod }^{-1}\end{array}$ & $\begin{array}{c}\text { No. } \\
\text { Seeds } \\
\text { plant }^{-1} \text { ) }\end{array}$ & $\begin{array}{c}100 \\
\text { grain } \\
\text { weight } \\
\text { (g) }\end{array}$ & $\begin{array}{l}\text { Grain } \\
\text { weight } \text { plant }^{-1} \\
\text { (g }\end{array}$ & $\begin{array}{l}\text { Height of } \\
\text { the } \\
\text { lowest } \\
\text { pod }\end{array}$ \\
\hline \multirow{2}{*}{$\mathrm{H}_{0}$} & $\overline{D_{1}}$ & $27.2 \mathrm{a}$ & $50.8 \mathrm{a}$ & $12.8 \mathrm{a}$ & $155.6 \mathrm{a}$ & $55.7 \mathrm{a}$ & $9.5 \mathrm{a}$ & $18.3 \mathrm{~d}$ & $1.2 \mathrm{bc}$ & $24.3 \mathrm{~d}$ & $20.9 f$ & $3.9 \mathrm{~d}$ & $42.8 \mathrm{~b}$ \\
\hline & $\mathrm{D}_{2}$ & $7.0 \quad c$ & $37.8 \mathrm{~b}$ & $4.5 \quad b c$ & $17.8 \quad b$ & $46.7 \mathrm{~cd}$ & $2.3 \quad b$ & $13.8 \mathrm{e}$ & $1.2 b c$ & $15.9 \mathrm{f}$ & $20.5 \mathrm{f}$ & $2.6 \mathrm{f}$ & $35.4 \quad c$ \\
\hline \multirow{2}{*}{$\mathrm{H}_{1}$} & $\mathrm{D}_{1}$ & $10.9 \mathrm{~b}$ & $35.2 \mathrm{~b}$ & $5.3 \quad b$ & $12.9 \quad b$ & $51.2 a b c$ & $5.3 \mathrm{ab}$ & $24.5 c$ & $1.2 \mathrm{~b}$ & $29.4 \mathrm{c}$ & $24.6 \mathrm{~d}$ & 4.9 & $42.6 \mathrm{~b}$ \\
\hline & $D_{2}$ & $2.6 \mathrm{~d}$ & 19.2 c & $2.1 d$ & $10.5 \quad b$ & 47.7bcd & $2.3 \quad b$ & $16.7 \mathrm{~d}$ & $1.1 \mathrm{c}$ & $19.8 \mathrm{e}$ & $22.7 \mathrm{e}$ & $3.2 \mathrm{e}$ & $37.4 \quad c$ \\
\hline \multirow{2}{*}{$\mathrm{H}_{2}$} & $\mathrm{D}_{1}$ & $3.5 \mathrm{~d}$ & $7.7 \mathrm{~d} \mathrm{e}$ & $3.7 \quad c$ & 3.7 & $52.3 \mathrm{ab}$ & $2.7 \quad b$ & $30.9 b$ & $1.2 \quad b$ & $39.4 b$ & $28.7 \mathrm{c}$ & $5.4 \quad b$ & $43.6 \mathrm{~b}$ \\
\hline & $\mathrm{D}_{2}$ & $1.9 \mathrm{~d}$ & $10.1 \mathrm{~d}$ & $1.9 \mathrm{~d}$ & 4.8 & $45.7 \quad d$ & $2.3 \quad b$ & $18.1 \mathrm{~d}$ & $1.2 \quad b$ & $19.0 \mathrm{e}$ & $25.0 \mathrm{~d}$ & $4.2 \mathrm{~d}$ & $35.2 \mathrm{c}$ \\
\hline \multirow{2}{*}{$\mathrm{H}_{3}$} & $\mathrm{D}_{1}$ & $1.9 \mathrm{~d}$ & $5.5 \mathrm{e}$ & $1.4 \mathrm{~d}$ & 3.9 & $48.4 \mathrm{bcd}$ & $2.7 \quad b$ & $43.1 \mathrm{a}$ & $1.4 \mathrm{a}$ & $56.4 \mathrm{a}$ & $31.0 \mathrm{a}$ & $6.0 \mathrm{a}$ & $52.0 \mathrm{a}$ \\
\hline & $\mathrm{D}_{2}$ & $1.2 \mathrm{~d}$ & $4.6 \mathrm{e}$ & $1.1 d$ & 2.4 & $46.0 \mathrm{~cd}$ & $3.1 \quad b$ & $32.0 \mathrm{~b}$ & $1.4 \mathrm{a}$ & $38.5 b$ & 29.9 b & 4.6 & $42.3 \quad b$ \\
\hline \multirow[t]{2}{*}{$p_{0}$} & $D_{1}$ & $13.5 \mathrm{a}$ & $32.1 \mathrm{a}$ & $6.7 \mathrm{a}$ & 53.9 a & $53.2 \mathrm{a}$ & $5.4 \mathrm{a}$ & $20.7 \mathrm{de}$ & $1.2 b c$ & $30.7 d$ & 22.9 e & $4.2 \quad c$ & $43.6 \quad b$ \\
\hline & $\mathrm{D}_{2}$ & $3.2 \mathrm{~d}$ & $21.9 \mathrm{bc}$ & $6.3 \mathrm{a}$ & $11.9 \quad c$ & $46.4 \quad b$ & $2.2 \mathrm{a}$ & $17.0 \mathrm{f}$ & $1.1 \mathrm{c}$ & $20.7 \mathrm{e}$ & $20.7 f$ & 2.5 & $36.7 \quad c$ \\
\hline \multirow{2}{*}{$p_{1}$} & $D_{1}$ & $12.1 \mathrm{ab}$ & $24.9 b$ & $5.3 \quad b$ & $39.2 \mathrm{ab}$ & $52.2 \mathrm{a}$ & $5.2 \mathrm{a}$ & $28.1 \mathrm{~b}$ & $1.2 a b$ & $34.8 \mathrm{c}$ & $25.7 \mathrm{~cd}$ & $5.0 \quad b$ & $44.7 \mathrm{ab}$ \\
\hline & $\mathrm{D}_{2}$ & $2.5 \mathrm{~d}$ & 17.5 ef & $4.9 \quad b$ & 8.0 & $45.5 \quad b$ & $2.6 \mathrm{a}$ & 18.2ef & $1.2 \mathrm{ab}$ & $22.3 \mathrm{e}$ & $24.9 \mathrm{~d}$ & $3.8 \mathrm{~d}$ & $37.8 \quad c$ \\
\hline \multirow[t]{2}{*}{$p_{2}$} & $D_{1}$ & $8.4 \quad c$ & $21.3 \mathrm{~cd}$ & 2.7 & $35.6 \quad b$ & $50.6 \mathrm{ab}$ & $4.6 \mathrm{a}$ & $33.1 \mathrm{a}$ & $1.3 \mathrm{ab}$ & $38.2 \mathrm{~b}$ & $28.1 \mathrm{a}$ & $5.5 \mathrm{a}$ & $45.1 \mathrm{ab}$ \\
\hline & $D_{2}$ & $3.5 \mathrm{~d}$ & 18.0def & 2.7 & 8.4 & $47.9 \mathrm{ab}$ & $2.6 \mathrm{a}$ & $21.2 \mathrm{~d}$ & $1.2 a b c$ & $22.4 \mathrm{e}$ & $25.9 b \mathrm{c}$ & $4.1 \mathrm{c} \mathrm{d}$ & $38.3 \quad c$ \\
\hline$p_{3}$ & $D_{1}$ & $9.6 \mathrm{bc}$ & $20.0 \mathrm{cde}$ & 2.2 & $45.9 \mathrm{ab}$ & $51.8 \mathrm{a}$ & $4.9 \mathrm{a}$ & $34.8 \mathrm{a}$ & $1.3 \mathrm{a}$ & $45.6 \mathrm{a}$ & $28.6 \mathrm{a}$ & $5.5 \mathrm{a}$ & $47.6 \mathrm{a}$ \\
\hline
\end{tabular}


Journal of University of Duhok., Vol. 20, No.1 (Agri. and Vet. Sciences), Pp 87-104, 2017

DOI: https://doi.org/10.26682/avuod.2017.20.1.11

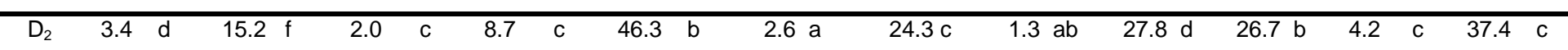

Means in each column followed by the same letter are not significantly different at the 5\% probability level according to Duncan's Multiple Range Test. 
Table (10) shows the triple interaction effect between treflan herbicide $(\mathrm{H})$, phosphorous $(\mathrm{P})$ and planting date $(\mathrm{T})$. The interaction $\left(\mathrm{H}_{0} \mathrm{P}_{0} \mathrm{D}_{1}\right)$ gave the highest number and dry weight of broad and narrow leaved weeds which recorded $(27.0,63.0 \mathrm{~g}, 14.3,96.2 \mathrm{~g}$ and plant height $57.4 \mathrm{~cm})$ while, the minimum values were $(1.0,2.5 \mathrm{~g}, 1.0$, and $1.2 \mathrm{~g})$ for the above traits recorded by $\mathrm{H}_{3} \mathrm{P}_{3} \mathrm{D}_{2}$ and $\mathrm{H}_{3} \mathrm{P}_{3} \mathrm{D}_{1}$. For the primary branches plant ${ }^{-1}$, the results showed non-significant effect by interaction between herbicide, phosphorous and planting dates. Whereas the interaction $\mathrm{H}_{3} \mathrm{P}_{3} \mathrm{D}_{1}$ gave the maximum values which were $1.5 \mathrm{t}, 76.4,34.3 \mathrm{~g}, 6.9 \mathrm{~g}$ and $58.3 \mathrm{~cm}$ for number of seed pod-1, seeds plant- ${ }^{1}, 100$-grain weight, grain yield plant ${ }^{-1}$ and height of the lowest pod. Form the results above all different levels of herbicide and phosphorous level were more effective to kill the broad and narrow leaved weeds in first stage of chickpea growth and help chickpea plant to improve the crop growth and useful from the different levels of phosphorous applications and increasing yield and yield components of chickpea plant. These results were consistent with the results proved by (Upadhyay and Bhalla, 2002 and Patel et al., 
Table (10): Effect of Interaction between treflan herbicide, phosphorus levels and planting dates on weeds and chickpea yield.

\begin{tabular}{|c|c|c|c|c|c|c|c|c|c|c|c|c|c|c|}
\hline $\mathrm{H}$ & $\mathrm{N}$ & $\mathrm{D}$ & $\begin{array}{c}\text { No of broad } \\
\text { leaf } \\
\text { weeds } / \mathrm{m}^{2}\end{array}$ & $\begin{array}{l}\text { Dry weight } \\
\text { of broad leaf } \\
\text { weeds } \mathrm{g} / \mathrm{m}^{2}\end{array}$ & $\begin{array}{c}\text { No of } \\
\text { narrow } \\
\text { leaf } \\
\text { weeds } / \mathrm{m}^{2}\end{array}$ & $\begin{array}{l}\text { dry weight of } \\
\text { narrow leaf } \\
\text { weeds }\left(\mathrm{g} / \mathrm{m}^{2}\right.\end{array}$ & $\begin{array}{l}\text { plant height } \\
\text { (cm) }\end{array}$ & $\begin{array}{l}\text { No. of } \\
\text { primary } \\
\text { branches } \\
\text { plant }^{-1}\end{array}$ & $\begin{array}{c}\text { No. of } \\
\text { pods plant }\end{array}$ & $\begin{array}{l}\text { No. of } \\
\text { seeds } \\
\text { pod }^{-1}\end{array}$ & $\begin{array}{l}\text { No. Seeds } \\
\text { plant }^{-1} \text { ) }\end{array}$ & $\begin{array}{l}100 \text { grain } \\
\text { weight }(\mathrm{g})\end{array}$ & $\begin{array}{l}\text { Grain yield } \\
\qquad \mathrm{g} \mathrm{m}^{-1}\end{array}$ & $\begin{array}{l}\text { Height of the } \\
\text { lowest pod }\end{array}$ \\
\hline \multirow{8}{*}{$\mathrm{H}_{0}$} & \multirow{2}{*}{$\mathrm{P}_{0}$} & $\mathrm{D}_{1}$ & $27.0 \mathrm{a}$ & $63.0 \mathrm{a}$ & $14.3 \mathrm{a}$ & $196.2 \mathrm{a}$ & $57.4 \mathrm{a}$ & $7.7 \mathrm{a}$ & $14.7 \mathrm{klm}$ & $1.2 \mathrm{~cd} \mathrm{e}$ & $24.4 \mathrm{j}-\mathrm{n}$ & 21.3ghi & $3.7 \mathrm{k} \mathrm{I}$ & $40.3 c-j$ \\
\hline & & $D_{2}$ & $6.7 \mathrm{de}$ & $46.2 \mathrm{bc}$ & $5.3 \mathrm{~cd}$ & $25.2 d$ & $45.8 \mathrm{ab}$ & $2.2 \mathrm{a}$ & $13.2 \mathrm{~m}$ & $1.1 \mathrm{de}$ & $15.0 p$ & $19.8 \mathrm{i}$ & $2.50 p$ & $37.9 e-j$ \\
\hline & \multirow{2}{*}{$\mathrm{P}_{1}$} & $\mathrm{D}_{1}$ & $30.3 \mathrm{a}$ & $53.9 \mathrm{~b}$ & $11.7 \mathrm{~b}$ & $136.4 \mathrm{bc}$ & $55.6 \mathrm{ab}$ & $9.3 \mathrm{a}$ & $14.6 \mathrm{klm}$ & $1.2 \mathrm{~cd} \mathrm{e}$ & $22.6 \mathrm{ko}$ & $20.4 \mathrm{~h} \mathrm{i}$ & $4.0 \mathrm{jkl}$ & $41.8 \mathrm{c}-\mathrm{i}$ \\
\hline & & $\mathrm{D}_{2}$ & $5.0 \mathrm{de}$ & 35.0 ef & $5.0 \mathrm{~cd}$ & $15.3 \mathrm{~d}$ & $45.1 \mathrm{ab}$ & $2.0 \mathrm{a}$ & $12.4 \quad \mathrm{~m}$ & $1.1 \mathrm{de}$ & $14.1 p$ & $20.3 \mathrm{~h} \mathrm{i}$ & $2.8 \mathrm{no}$ & $33.4 \mathrm{j}$ \\
\hline & \multirow{2}{*}{$\mathrm{P}_{2}$} & $\mathrm{D}_{1}$ & $24.7 \mathrm{a}$ & $43.4 \mathrm{~cd}$ & $12.3 a b$ & $121.5 \mathrm{c}$ & $54.0 \mathrm{ab}$ & $10.1 \mathrm{a}$ & $21.3 \mathrm{f}-\mathrm{k}$ & $1.1 \mathrm{de}$ & $25.0 \mathrm{im}$ & $20.5 \mathrm{~h} \mathrm{i}$ & 4.5 hij & $42.1 c-i$ \\
\hline & & $\mathrm{D}_{2}$ & $7.0 \mathrm{de}$ & 34.7 ef & 4.7 cde & $16.3 \mathrm{~d}$ & $48.7 \mathrm{ab}$ & $2.3 \mathrm{a}$ & $13.9 \mathrm{Im}$ & $1.2 \mathrm{cde}$ & 15.6 op & $21.6 \mathrm{ghi}$ & $2.6 \circ p$ & 35. $\mathrm{h}$ ij \\
\hline & \multirow{2}{*}{$P_{3}$} & $D_{1}$ & $27.0 \mathrm{a}$ & $42.9 \mathrm{ce}$ & $12.7 \mathrm{a} b$ & 168.2ab & $55.9 \mathrm{ab}$ & $10.8 \mathrm{a}$ & 22.5 e- j & $1.2 \mathrm{cde}$ & $25.1 \mathrm{im}$ & 21.3ghi & $3.5 \mathrm{lmn}$ & $47.1 \mathrm{bcd}$ \\
\hline & & $\mathrm{D}_{2}$ & $9.3 \mathrm{bcd}$ & 35.4def & $3.0 \mathrm{~d}-\mathrm{i}$ & $14.5 \mathrm{~d}$ & $47.3 \mathrm{ab}$ & $2.7 \mathrm{a}$ & $15.8 \mathrm{j}-\mathrm{m}$ & $1.2 \mathrm{cde}$ & $18.8 \mathrm{mp}$ & $20.4 \mathrm{~h} \mathrm{i}$ & $2.3 \circ p$ & 35.0 hij \\
\hline \multirow{8}{*}{$\mathrm{H}_{1}$} & \multirow{2}{*}{$P_{0}$} & $D_{1}$ & $16.0 \quad b$ & $45.5 \mathrm{c}$ & $\begin{array}{ll}6.7 & c\end{array}$ & $12.5 \mathrm{~d}$ & $51.9 \mathrm{ab}$ & $6.8 \mathrm{a}$ & 23.2 e-i & $1.2 \mathrm{cde}$ & $28.6 \mathrm{~g}-\mathrm{k}$ & $19.9 \quad \mathrm{i}$ & $4.1 \mathrm{i}-\mathrm{I}$ & $48.5 \mathrm{~b} \mathrm{c}$ \\
\hline & & $\mathrm{D}_{2}$ & $3.0 \mathrm{de}$ & $22.5 \mathrm{~g}$ & 2.3 e- i & $14.6 \quad d$ & $44.4 \mathrm{ab}$ & $2.1 \mathrm{a}$ & $13.5 \quad \mathrm{~m}$ & $\begin{array}{ll}1.1 & \mathrm{e}\end{array}$ & $19.3 m-p$ & $20.6 \mathrm{gh} \mathrm{i}$ & $\begin{array}{ll}2.1 & p\end{array}$ & $37.0 \mathrm{f}-\mathrm{j}$ \\
\hline & \multirow{2}{*}{$P_{1}$} & $\mathrm{D}_{1}$ & $14.0 \mathrm{bc}$ & $34.0 \mathrm{f}$ & $3.7 \mathrm{~d}-\mathrm{h}$ & $13.9 \mathrm{~d}$ & $52.1 \mathrm{ab}$ & $6.9 \mathrm{a}$ & 25.4 ef g & $1.2 \mathrm{~cd} \mathrm{e}$ & $27.5 \mathrm{~h}-\mathrm{I}$ & 25.3 cde & $4.7 \mathrm{~g}-\mathrm{j}$ & $39.3 \mathrm{~d}-\mathrm{j}$ \\
\hline & & $\mathrm{D}_{2}$ & 2.3 & $20.2 \mathrm{~g} \mathrm{~h}$ & $2.0 \mathrm{f}-\mathrm{i}$ & 7.6 & $48.4 \mathrm{ab}$ & $2.6 \mathrm{a}$ & 17.2 h-m & $\begin{array}{ll}1.1 & \mathrm{e}\end{array}$ & $19.2 m-p$ & $22.5 \mathrm{fgh}$ & $3.5 \mathrm{I}-\mathrm{m}$ & 38.0 e-j \\
\hline & \multirow{2}{*}{$\mathrm{P}_{2}$} & $D_{1}$ & $6.3 \mathrm{de}$ & $33.2 \mathrm{f}$ & $4.3 \mathrm{c}-\mathrm{f}$ & $14.2 d$ & $51.0 \mathrm{ab}$ & $3.9 \mathrm{a}$ & 24.0 e-h & 1.3 b-e & $27.1 \mathrm{~h}-\mathrm{I}$ & 27.0 & $5.1 \mathrm{~d}-\mathrm{h}$ & $38.9 d-j$ \\
\hline & & $\mathrm{D}_{2}$ & $3.3 \mathrm{de}$ & $22.3 \mathrm{~g}$ & $2.0 \mathrm{f}-\mathrm{i}$ & 8.7 & $49.9 \mathrm{ab}$ & $2.5 \mathrm{a}$ & $17.1 \mathrm{i}-\mathrm{m}$ & $\begin{array}{ll}1.1 & \mathrm{e}\end{array}$ & $19.5 m-p$ & 23.1 e $f \mathrm{~g}$ & $3.5 \mathrm{Im}$ & 38.4 e-j \\
\hline & \multirow{2}{*}{$\mathrm{P}_{3}$} & $D_{1}$ & $7.3 \mathrm{cde}$ & $28.4 \mathrm{fg}$ & 6.7 & 11.1 & $50.0 \mathrm{ab}$ & $3.8 \mathrm{a}$ & 25.2 efg & $1.2 \mathrm{c} \mathrm{de}$ & $34.2 \mathrm{e}-\mathrm{h}$ & $26.3 \mathrm{~cd}$ & $5.7 \mathrm{cde}$ & $43.8 \mathrm{c}-\mathrm{g}$ \\
\hline & & $D_{2}$ & 1.7 & $11.8 \mathrm{ij}$ & $2.0 \mathrm{f}-\mathrm{i}$ & $10.9 \quad d$ & $48.1 \mathrm{ab}$ & $2.2 \mathrm{a}$ & $19.0 \mathrm{~g}-\mathrm{m}$ & $1.2 \mathrm{de}$ & $21.21-p$ & 24.8 c-f & $3.7 \mathrm{k} \mathrm{I}$ & $36.0 \mathrm{~g}-\mathrm{j}$ \\
\hline $\mathrm{H}_{2}$ & $\mathrm{P}_{0}$ & $D_{1}$ & $\mathrm{de}$ & $13.5 \mathrm{~h} \mathrm{i}$ & $4.0 \mathrm{~d}-\mathrm{g}$ & 3.2 & $53.3 \mathrm{ab}$ & $4.3 \mathrm{a}$ & 24.3 e f g & $1.2 \mathrm{~cd} \mathrm{e}$ & 37.6 ef & $25.6 \mathrm{~cd}$ & 4.4 h-k & 45.2 c-f \\
\hline
\end{tabular}




\begin{tabular}{|c|c|c|c|c|c|c|c|c|c|c|c|c|c|c|c|c|}
\hline & & $\mathrm{D}_{2}$ & 1.7 & $\overline{\mathrm{e}}$ & $10.9 \mathrm{i} \mathrm{jk}$ & $2.0 \mathrm{f}-\mathrm{i}$ & 3.8 & $\bar{d}$ & $47.8 \mathrm{ab}$ & $2.1 \mathrm{a}$ & $14.4 \mathrm{Im}$ & $1.2 \mathrm{cde}$ & $17.8 m-p$ & $21.3 \mathrm{~g} \mathrm{~h} \mathrm{i}$ & 2.7 nop & $36.0 \mathrm{~g}-\mathrm{j}$ \\
\hline & \multirow{2}{*}{$P_{1}$} & $D_{1}$ & 2.3 & $\mathrm{e}$ & $6.3 \mathrm{i}-\mathrm{I}$ & $4.0 \mathrm{~d}-\mathrm{g}$ & 3.6 & $d$ & $54.4 \mathrm{ab}$ & $2.2 \mathrm{a}$ & $28.3 \mathrm{de}$ & 1.2 cde & 35.7 efg & $24.4 \mathrm{def}$ & $5.5 \mathrm{cf}$ & $43.6 \mathrm{c}-\mathrm{g}$ \\
\hline & & $\mathrm{D}_{2}$ & 1.7 & e & $8.5 \quad \mathrm{i}-\mathrm{I}$ & $2.3 \quad e-i$ & 5.6 & $\mathrm{~d}$ & $44.3 \mathrm{ab}$ & $2.7 \mathrm{a}$ & 16.3 j-m & $1.1 \mathrm{de}$ & $16.0 \circ p$ & $25.4 \mathrm{~cd} \mathrm{e}$ & $4.2 \mathrm{i}-\mathrm{I}$ & $34.3 \mathrm{ij}$ \\
\hline & \multirow{2}{*}{$\mathrm{P}_{2}$} & $D_{1}$ & 1.7 & $\mathrm{e}$ & $4.5 \mathrm{jk} \mathrm{I}$ & $2.0 \mathrm{f}-\mathrm{i}$ & 4.8 & $d$ & $49.6 \mathrm{ab}$ & $1.9 \mathrm{a}$ & $34.1 \mathrm{~cd}$ & 1.2 cde & 37.4 ef & $32.3 \mathrm{ab}$ & $6.0 \mathrm{bc}$ & $44.5 \mathrm{c}-\mathrm{f}$ \\
\hline & & $\mathrm{D}_{2}$ & 2.7 & $\mathrm{de}$ & $10.8 \mathrm{i}-\mathrm{I}$ & $\begin{array}{ll}1.3 \mathrm{hi} \\
\end{array}$ & 4.4 & $d$ & $47.0 \mathrm{ab}$ & $2.3 \mathrm{a}$ & $19.2 \mathrm{~g}-\mathrm{m}$ & $1.2 \mathrm{cde}$ & 17.2nop & $26.3 \mathrm{~cd}$ & $4.8 \mathrm{f}-\mathrm{i}$ & $34.8 \mathrm{hij}$ \\
\hline & \multirow{2}{*}{$\mathrm{P}_{3}$} & $\mathrm{D}_{1}$ & 3.0 & $d e$ & $6.4 \mathrm{i}-\mathrm{I}$ & $4.7 \mathrm{c} \mathrm{de}$ & 3.2 & $\mathrm{~d}$ & $51.9 \mathrm{ab}$ & $2.2 \mathrm{a}$ & 36.9 & $1.2 \mathrm{cde}$ & $46.9 \mathrm{~cd}$ & $32.5 \mathrm{ab}$ & $5.8 \mathrm{bcd}$ & $41.2 \mathrm{c}-\mathrm{j}$ \\
\hline & & $\mathrm{D}_{2}$ & 1.7 & $\mathrm{e}$ & $10.2 \mathrm{i}-\mathrm{I}$ & $2.0 \mathrm{f}-\mathrm{i}$ & 5.5 & $d$ & $43.7 \quad b$ & $2.1 \mathrm{a}$ & 22.4 & $1.3 \mathrm{cde}$ & $24.9 \mathrm{i}-\mathrm{m}$ & 27.0 & $5.0 \mathrm{e}-\mathrm{h}$ & $35.7 \mathrm{~g}-\mathrm{j}$ \\
\hline \multirow{8}{*}{$\mathrm{H}_{3}$} & \multirow{2}{*}{$\mathrm{P}_{0}$} & $\mathrm{D}_{1}$ & 4.0 & $\mathrm{de}$ & $6.3 \mathrm{i}-\mathrm{I}$ & $1.7 \mathrm{~g} \mathrm{~h} \mathrm{i}$ & 3.7 & $d$ & $50.0 \mathrm{ab}$ & $2.9 \mathrm{a}$ & 20.5 & $1.2 \mathrm{~cd} \mathrm{e}$ & $32.1 \mathrm{f}-\mathrm{i}$ & $24.6 c-f$ & $4.5 \mathrm{~h} \mathrm{i} \mathrm{j}$ & $40.4 \mathrm{c}-\mathrm{j}$ \\
\hline & & $\mathrm{D}_{2}$ & 1.7 & $\mathrm{e}$ & $8.0 \quad \mathrm{i}-\mathrm{I}$ & 1.0 & 4.2 & $d$ & $47.7 \mathrm{ab}$ & $2.4 \mathrm{a}$ & 26.8 ef & $1.1 \mathrm{de}$ & $30.7 \mathrm{f}-\mathrm{j}$ & $21.2 \mathrm{~g} \mathrm{~h} \mathrm{i}$ & $2.7 \circ p$ & $35.8 \mathrm{~g}-\mathrm{j}$ \\
\hline & \multirow{2}{*}{$\mathrm{P}_{1}$} & $D_{1}$ & 1.7 & $\mathrm{e}$ & $5.4 \quad \mathrm{i}-\mathrm{I}$ & $1.7 \mathrm{~g} \mathrm{~h} \mathrm{i}$ & 2.7 & $d$ & $46.7 \mathrm{ab}$ & $2.3 \mathrm{a}$ & $44.1 \quad \mathrm{~b}$ & $1.4 a b c$ & 53.5 & $32.7 \mathrm{ab}$ & $5.9 \mathrm{bc}$ & $54.1 \mathrm{ab}$ \\
\hline & & $\mathrm{D}_{2}$ & 1.0 & $\bar{e}$ & $\begin{array}{ll}6.3 & \mathrm{i}-\mathrm{I}\end{array}$ & $1.3 \mathrm{hi}$ & 3.4 & $d$ & $44.3 \mathrm{ab}$ & $3.1 \mathrm{a}$ & 26.7 ef & 1.5 & $39.9 \mathrm{de}$ & $31.3 b$ & $\begin{array}{ll}4.8 \mathrm{f}-\mathrm{i} \\
\end{array}$ & 45.5 cde \\
\hline & \multirow{2}{*}{$\mathrm{P}_{2}$} & $\mathrm{D}_{1}$ & 1.0 & $\mathrm{e}$ & $4.1 \mathrm{jk} \mathrm{I}$ & 1.0 & 2.0 & $d$ & $47.7 \mathrm{ab}$ & $2.7 \mathrm{a}$ & 53.0 & $1.5 \mathrm{ab}$ & $63.5 \quad b$ & $32.6 \mathrm{ab}$ & $6.5 \mathrm{ab}$ & $55.0 \mathrm{ab}$ \\
\hline & & $\mathrm{D}_{2}$ & 1.0 & $\mathrm{e}$ & $4.3 \mathrm{jk} \mathrm{I}$ & 1.0 & 4.4 & $\mathrm{~d}$ & $46.0 \mathrm{ab}$ & $3.4 \mathrm{a}$ & $34.4 \mathrm{~cd}$ & $1.3 \mathrm{a}-\mathrm{d}$ & 37.3 ef & $32.6 \mathrm{ab}$ & $5.4 \mathrm{c}-\mathrm{g}$ & $45.0 \quad c-f$ \\
\hline & \multirow{2}{*}{$\mathrm{P}_{3}$} & $D_{1}$ & 1.0 & $\mathrm{e}$ & 2.51 & $1.3 \mathrm{~h} \mathrm{i}$ & 1.2 & $d$ & $49.3 \mathrm{ab}$ & $2.8 \mathrm{a}$ & $54.7 \mathrm{a}$ & $1.5 \mathrm{a}$ & $76.4 \mathrm{a}$ & 34.3 & $6.9 \mathrm{a}$ & $58.3 \quad \mathrm{a}$ \\
\hline & & $\mathrm{D}_{2}$ & 1.0 & $\mathrm{e}$ & $\begin{array}{ll}3.3 \mathrm{kl} \\
\end{array}$ & 1.0 & 3.7 & $d$ & $46.0 \mathrm{ab}$ & $3.6 \mathrm{a}$ & $40.0 \quad b c$ & $1.5 \mathrm{ab}$ & $46.3 \mathrm{~cd}$ & 34.6 & $5.7 \mathrm{cde}$ & $42.9 \mathrm{c}-\mathrm{h}$ \\
\hline
\end{tabular}

Means in each column followed by the same letter are not significantly different at the 5\% probability level according to Duncan's Multiple Range Test 


\section{REFERENCES}

- Ahlawat, I. P. S., Singh, A. and Saraf , C, S. 1981.Effect of winter legumes on the nitrogen economyand productivity of succeeding cereals. Experimental Agriculture 17: 57-62.

- Auld, P. and Lee, G. A. 1981. Chickpea, a potential pulse crop for northern Idaho. Current Information Services. Idabo Agricultural Experiment Station No. 570.

- Bhalla, U. S. (2002a) Use of Kinetikit and GENESIS for modeling signaling pathways. Meth. Enzymol. ,345: 3-23. (http://doqcs. ncbs.res.in/).

- Bhalla. C. S, S. P. Kurchaniaad, N. R. Paradkar. 1998. Herbicidal weed control in chickpea (Cicer ariteinum L.). World weeds, J. (12):121-124.

- Faroda, A. S. and Sing R. C. 1981. Weed control in pulses. Pulse Crop Newsletter 1: 50-51.

- Faroda, A. S. and Sing R. C. 1981. Weed control in pulses. Pulse Crop Newsletter 1: 50-51.

- Gawai P.P. and V. S. Pawar. 2007. Nutrient balance under INMS in sorghum chick pea cropping sequence. Indian J. Agric. Res., 41(2): 137-141.

- Gebreyeus, Br, Te, 2014. Response of yield and yield component of Tef [Eragrostis tef(Zucc.) Trotter] to tillage, nutrient, and weed mangment practices in Dura Area, Northern Ethipia. International Scholarly Research Notices. N. 439718. 9-19.

- Hassan, G. Khan. T. 2007. Post emergence herbicides control asphodels tenuifolius in desi chickpea ( Cicer arietinum L.)Luckv Marwat, Pakistan,Pak. J. weed Sci. Res. 13(1-2, 33-3

- Holmes, R. C, and C. L. Sprague. 2013. Row width affects weed management in Type II black bean. Weed control. 27, 3 P: 538-546.

- Kumar, B. V and Sreenivasulu. 2004. Integrated nutrient management. Sci. Teck: the Hindu, online Edition of India's National newspaper, Thursday $12^{\text {th }}$ August. 2004.

- Mahajan, A and R. Sharma. 2005. Integrated management ( INM) system-concept, need and future strategy. Agrobios NewsLetter, 4(3): 2932.

- Muhammad. A, A-Anwar, A-Arif, M. Nadeem and A. Zahid. 2010. Screening of pre and post emergence herbicides against chick pea (Cicer arietinum L.) weeds under semi rain fed conditions of Pothohar, Pakistan. Pak. J. Weed sci. Res. 16 (4): 421-430.

- Patel, B. D., J. B. Patel and R. B. Patel. 2006. Effect of fertilizer and weed management practices on weed control in chickpea (Cicer arietinum L) ander middle Gujarat conditions. Indian J. crop science, 1 (1-2) : 180-183.
- Sawhncy, V., Amarjit, and Singh, R. 1985. Effect of applied nitrate on growth and $\mathrm{N}$ - fixation in Cicer arientinum L. Plant and Soil 86: 233-240.

- Sexena, Mc. (1976). Problems and potential of chickpea production in the nineties. Proc. $2 \mathrm{~d} 2$ inter, workshop on chickpea improvement, ICRISAT Center, India, pp 13-28.

- Shabeer K. B. Shahbaz. 2015. Effect of phosphorous levels on growth and r. A. B; K. Mian; U. B. Sana; and yield of chick pea (Cicer avetinum L.) varieties. Journal of Natural science Research. 5. 3 164- 176.

- Steel, R. G. D and J. H Torrie, 1984. Principle and procedures of statistics. 2nd ed. MC Graw Hill Book Co-Singapore PP : 172-177.

- Teuwari A. N. Tiwari S. N. Rathi J.P.S. Verma R. N. Tripathi A. K. 2001. Crop weed competition studies having Asphodelus tenuifolius dominated weed community condition under rain fed condition. Ind J. Weed Sci, 33:198-199.

- Thorat, S. T. 2004. Effect of irrigation regimes, weed management and growth regulators on protein and dry pod yield of ground nut grown under polythene mulch. Inter. Arachis Newsletter, 24 : 45- 47.

- Upadhyay, V. B and C. S. Bhalla. 2002. Efficacy of cultural mechanical and chemical weed control in chickpea (Cicer aretinumL.). Indian. J. Weed sci. 34: 141-142.

- Yadav. D. S. and S. B. Sing .(1988). Efficacy of mechanical and chemical weed control in chickpea (Cicer ariteinum L.). Ann. Agric.Res. $9 \quad$ (2): $\quad 256 \quad-\quad 258$. 


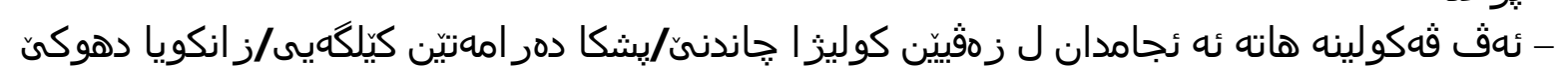

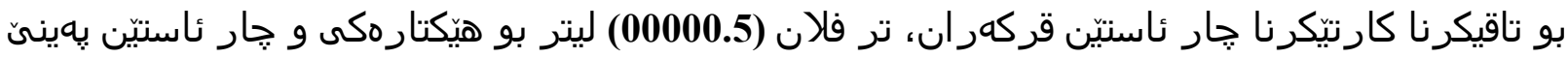

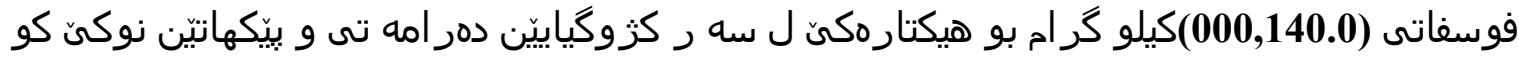

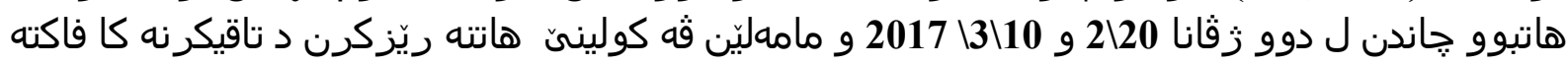

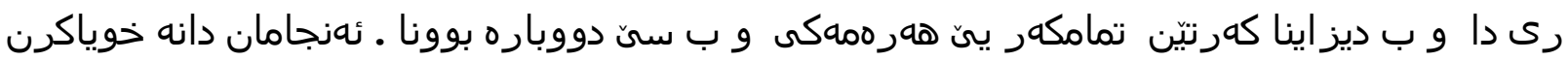

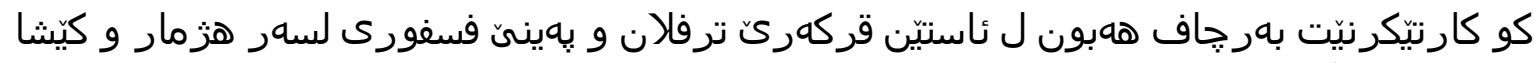

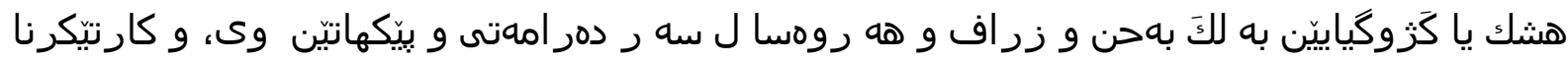

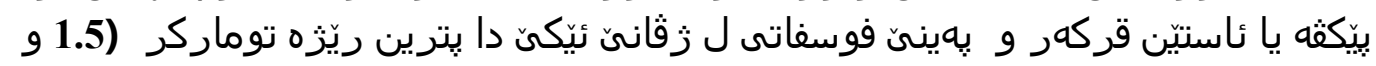

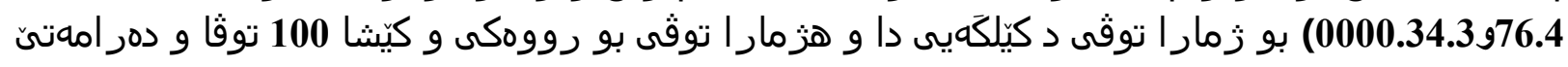

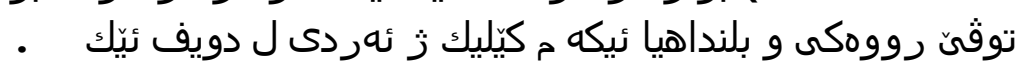

تأثير مستويات مختلفة من مبيد الترفلان والسماد الفوسفاتي على الادغال وحاصل الحمص.

الخلاصة

نفذت تجربة حقلية في حقل تجارب قسم المحاصيل الحقلية / كلية الزداعة جامعة دهوك لدر اسة تأثير

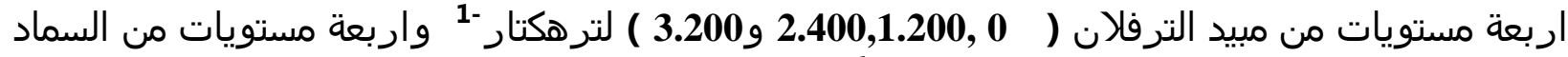

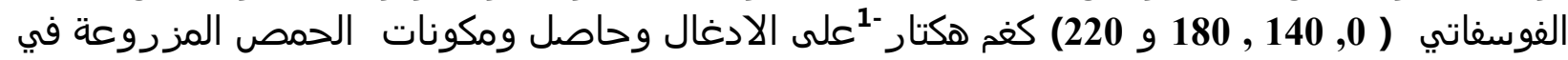

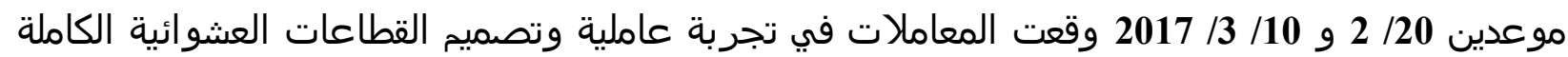

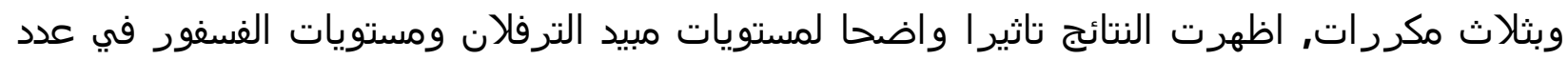

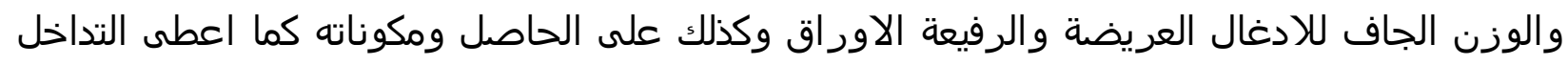

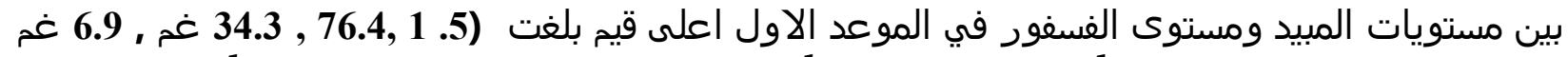

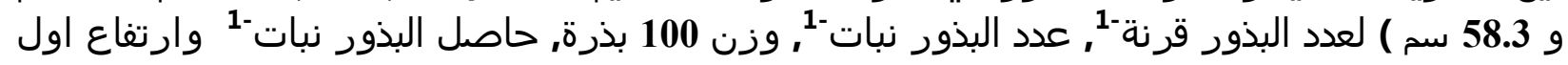
قرنة من الارض على التوالي.. 